\title{
NSU
}

Florida

Nova Southeastern University

NOVA SOUTHEASTERN

UNIVERSITY

NSUWorks

Faculty Scholarship

Shepard Broad College of Law

$1-1-2011$

\section{Schiavo Revisited? The Struggle for Autonomy at the End of Life in Italy}

Kathy L. Cerminara

Nova Southeastern University - Shepard Broad College of Law, cerminar@nova.edu

Follow this and additional works at: https://nsuworks.nova.edu/law_facarticles

Part of the Health Law and Policy Commons

\section{Recommended Citation}

Kathy Cerminara, Schiavo Revisited? The Struggle for Autonomy at the End of Life in Italy, 12 Marquette University Elder's Advisor 295 (2011).

This Article is brought to you for free and open access by the Shepard Broad College of Law at NSUWorks. It has been accepted for inclusion in Faculty Scholarship by an authorized administrator of NSUWorks. For more information, please contact nsuworks@nova.edu. 


\section{Marquette Elder's Advisor}

Volume 12

Issue 2 Spring

Article 3

\section{Schiavo Revisited? The Struggle for Autonomy at the End of Life in Italy}

Kathy L. Cerminara

Nova Southeastern University Shepard Broad Law Center

Federico Gustavo Pizzetti

University of Milan, Italy

Watcharin H. Photangtham

Follow this and additional works at: http://scholarship.law.marquette.edu/elders

Part of the Elder Law Commons

\section{Repository Citation}

Cerminara, Kathy L.; Pizzetti, Federico Gustavo; and Photangtham, Watcharin H. (2011) "Schiavo Revisited? The Struggle for Autonomy at the End of Life in Italy," Marquette Elder's Advisor: Vol. 12: Iss. 2, Article 3.

Available at: http://scholarship.law.marquette.edu/elders/vol12/iss2/3

This Article is brought to you for free and open access by the Journals at Marquette Law Scholarly Commons. It has been accepted for inclusion in Marquette Elder's Advisor by an authorized administrator of Marquette Law Scholarly Commons. For more information, please contact megan.obrien@marquette.edu. 


\title{
SCHIAVO REVISITED? THE STRUGGLE FOR AUTONOMY AT THE END OF LIFE IN ITALY
}

\author{
Kathy L. Cerminara*, Federico Gustavo Pizzetti** \& Watcharin \\ H. Photangtham ${ }^{* * *}$
}

Politically strident debates surrounding end-of-life decisionmaking have surfaced once again, this time across the Atlantic in Italy. Eluana Englaro died in 2009 after a prolonged court fight, causing the international press to compare her case to that of Theresa Marie Schiavo, who passed away in 2005 in Florida after nearly

This Article's analysis of proposed Italian legislation was current as of August, 2010. Political debate has, however, continued in Italy, so that any legislation eventually passed may differ in important ways from that discussed here.

* Kathy L. Cerminara, Professor of Law at the Nova Southeastern University Shepard Broad Law Center, is co-author of the nationally known treatise on end-of-life law, The Right to Die: The Law of End-ofLife Decisionmaking (3d ed. Aspen 2004 \& annual supps.). She received her J.D. from the University of Pittsburgh School of Law and her LL.M. and J.S.D. from Columbia University School of Law. She would like to thank Christopher Brown, Christopher Davis-Traina and Maria Albanese for their excellent assistance on this piece.

* Frederico Gustavo Pizzetti is a Professor of Public Law and a member of the faculty of political science at the University of Milan, Italy. Professor Pizzetti received his law degree from The Faculty of Law University in Turin, Italy, in 1999, graduating magna cum laude. His research and publication interests include end-life decisionmaking, governmental issues, and multi-level constitutionalism.

*** Watcharin H. Photangtham is currently an LL.M. (tax) candidate 2011 at New York University School of Law. He received his law degree, graduating magna cum laude in 2009 from the University of Miami School of Law. He received his B.A. in 1996 from the University of Virginia. I would like to thank my partner James Russell Stein. My contribution to this article would not be possible without his love and support. 
sparking constitutional crises on both state and federal levels. In many respects, the facts of Ms. Englaro's case are similar to those of Schiavo, but a close analysis of Englaro leads to the surprising conclusion that the Italian Court of Cassazione in that case actually enunciated a broader, stronger right to make end-of-life decisions than has the United States Supreme Court thus far in America.

The parallels between Englaro and Schiavo in the legislature are also instructive. In a number of ways, despite the breadth of the Cassazione's judicial decision in Englaro, institutional differences seem to be leading Italy down a different path in the Parliament than the United States has taken through the federal or its several state legislatures. Despite the introduction of advance directive legislation in Parliament, it seems that Italy's path toward patients' preserving robust end-of-life decisionmaking power even in incompetency lies not through that body's actions in the future but through that body's past actions. If the current proposed legislation fails, it is possible that patients and the courts can build upon the groundwork the courts have established through the statutory tool of the amministratore di sostegno to secure robust patient autonomy near the end of life.

The debates surrounding end-of-life decisionmaking have surfaced once again, this time across the Atlantic in Italy. The international press covering Eluana Englaro's ${ }^{1}$ (Ms. Englaro's) end-of-life decisionmaking litigation compared Ms. Englaro's case to that of Theresa Marie Schiavo ${ }^{2}$ (Ms. Schiavo). In many respects, the facts of Ms. Englaro's case (Englaro) are similar to Ms. Schiavo's. ${ }^{3}$ Both women were in the prime of their lives ${ }^{4}$

1. Eluana Englaro died on Monday, February 9, 2009, after a prolonged court fight initiated by her father, Beppino Englaro, to honor her wish to die in a dignified way. See Richard Owen, Coma Woman Dies According to Her Wish Before Parliament Can Resume Feeding, THE TIMES (LONDON), Feb. 10, 2009, at 32.

2. See Id. See also Paddy Agnew, Eluana's 17-Year Sleep Caught up in Legal Row Over Treatment, THE IRISH TIMES, Jan. 28, 2009, at 13; Peter Popham, Church Fury as Coma Woman Allowed to Die; Italian Court Grants Father Right to End Daughter's Life, THE INDEPENDENT (LONDON), Nov. 14, 2008, at 32; Ariel David, Italians Debate Case Like Schiavo's, ORLANDO SENTINel, Aug. 2, 2008, at A.7; John Hooper, Ruling on Coma Victim Brings Euthanasia Issue to Fore in Italy, THE IRISH TIMES, July 11, 2008, at 11.

3. See Donald Carroll \& Christine Marciasini, Advance Care Directives: Florida, 
when they fell into a persistent or permanent vegetative state (PVS); ${ }^{5}$ both women lacked living wills expressing their desires as to what type of care they wished to receive in the event that they were no longer able to make decisions due to illness or incapacity; and neither had appointed a healthcare proxy. Indeed, Ms. Englaro could not have had a living will or appointed a health care proxy because Italy had no legislation specifically authorizing anticipatory end-of-life decisionmaking. ${ }^{6}$

While the factual circumstances of Ms. Englaro and Ms. Schiavo were similar, the end-of-life decisionmaking laws facing the two women were not. By the time Ms. Schiavo fell into a PVS, there existed a well-established body of laws concerning end-of-life decisionmaking. Florida, the jurisdiction whose laws applied in Ms. Schiavo's case, had codified such laws, specifically permitting the withholding or withdrawal of "lifeprolonging procedures" from a person in a PVS without an advance directive under certain conditions. ${ }^{8}$ In contrast, the litigation that Ms. Englaro's father (Mr. Englaro) brought on her behalf to discontinue life-prolonging procedures was fraught

Italy and the Holy Grail of Wishes, 2 (on file with the authors) (noting that Ms. Englaro "is known in Italy as the 'Italian Terri Schiavo"). Compare Kathy L. Cerminara, Theresa Marie Schiavo's Long Road to Peace, 30 DEATH STUDIES 101 (2006). [hereinafter Cerminara, Long Road to Peace] (detailing Ms. Schiavo's story) with Michael Day \& Tracy McVeigh, National: Special Report: A Father's Plea, THE OBSERVER (England), Feb. 8, 2009, at 8 (interview with Ms. Englaro's father about her story).

4. Ms. Englaro was 20 years old while Ms. Schiavo was 27 years old.

5. Coincidentally, both women fell into PVS only two years apart from each other. See David, supra note 2 ("Englaro was 20 years old when she fell into a vegetative state after a car accident in 1992."). See Cerminara, Long Road to Peace, supra note 3, at 102. For an interactive timeline of the Terri Schiavo's case, see Kathy L. Cerminara \& Kenneth W. Goodman, Key Events in the Case of Theresa Marie Schiavo, UNIV. OF MIAMI-ETHICS PROGRAMS, http://www.miami.edu/ethics/schiavo /terri_schiavo_timeline.html (last updated Dec. 27, 2008) [hereinafter Cerminara, Key Events].

6. The Italian Parliament had previously considered such legislative proposals, and it has continued to do so during and since the courts ruled in Englaro. See infra $\mathrm{p}$ 320-28. There already existed under Italian law a legislative framework that could apply by extension to health care decisions, through the Act on "amministrazione di sostegno," see infra p. 328-60, but nothing specific existed.

7. FLA. STAT. §765.101-546 (1997).

8. $\S 765.404$ (allowing the withdrawal of life-prolonging procedures for a patient in PVS if the patient had no advance directive). 
with legal obstacles because of the uncertainty in Italian end-oflife decisionmaking law in dealing with Ms. Englaro's situation.

This Article will compare and analyze the legal development of Italian end-of-life decisionmaking law with that in the United States through Ms. Englaro's and Ms. Schiavo's court cases. Section I will trace the development of end-of-life decisionmaking law in the U.S. up to the Schiavo litigation. Section II will outline and comment on Ms. Schiavo's litigation process while Section III will similarly describe Ms. Englaro's litigation process and outcome. Section IV will compare Italian end-of-life decisionmaking law to U.S. end-of-life decisionmaking law, emphasizing the significance of Ms. Englaro's case. Finally, Section V will demonstrate how the path pursuant to which Italian end-of-life decisionmaking law is developing far more closely resembles the development of U.S. end-of-life decisionmaking law than one might predict given the countries' differing cultural backgrounds and political and judicial systems. Despite the similarities in path, substantial differences exist, in some rather surprising areas.

\section{THE DEVELOPMENT OF UNITED STATES END-OF-LIFE DECISIONMAKING LAW}

Fundamentally, end-of-life decisionmaking is the right or ability to refuse life-sustaining or life-prolonging treatments when patients no longer wish to receive such treatments. Scholars and end-of-life decisionmaking advocates ${ }^{9}$ have argued that this right encompasses the right to assistance in dying and even to euthanasia for patients suffering from terminal illness. But whereas the courts and various legislatures have recognized the

9. See, e.g., Norman L. Cantor, Two Opinions in Search of a Justice: The Constitution and Physician-Assisted Suicide, 28 RUTGERS L.J. 435 (1997); Sylvia A. Law, Physician-Assisted Death: An Essay on Constitutional Rights and Remedies, 55 MD. L. REV. 292 (1996); David Orentlicher, The Alleged Distinction Between Euthanasia and the Withdrawal of Life-Sustaining Treatment: Conceptually Incoherent and Impossible to Maintain, U. ILL. L. REV. 837 (1998). But see, e.g., Yale Kamisar, The "Right to Die": On Drawing (and Erasing) Lines, 35 DUQ. L. REV. 481 (1996). 
right to refuse life-prolonging treatment, ${ }^{10}$ and even assistance in dying, ${ }^{11}$ the courts have affirmatively held that no person has the constitutional right to euthanasia. ${ }^{12}$ Indeed, the blurring and confusion of this distinction in the continuum between the right to refuse life-prolonging treatment and euthanasia make end-oflife decision discussions contentious. This is especially true when a private medical decision of an individual takes on a public dimension, as it does when the decision is litigated in court to resolve conflicts. At least one of the major conflicts inherent in end-of-life decisionmaking arises because of a clash of competing choices between preserving life ${ }^{13}$ (perhaps at all costs, including discarding the wishes of the individual $)^{14}$ and personal autonomy. ${ }^{15}$ At the intersection between these two

10. See Alan Meisel \& Kathy L. Cerminara, The Right to Die: The Law of END-OF-LIFE DECISIONMAKING \$2.02 (3d. ed. 2004 \& Supp. 2005-2009). [hereinafter THE RIGHT TO DIE].

11. E.g., OR. Rev. STAT. § 127.800-.897 (1999); WASH. Rev. CODE ANN. $\$ 70.245 .010$-.904 (West 2009); Baxter v. State, No. ADV-2007-787 at 17 (Mont. 1st Dist. Ct. Dec. 5, 2008) available at http://www.aclumontana.org/images/stories/ documents/081208-district-court-opinion-baxter.pdf.

12. Euthanasia generally refers to "the 'active' ending of the life of another in order to end that patient's suffering." THE RIGHT TO DIE, supra note 10, at $\$ 12.01$ [A]. This is distinct from assistance in dying and withholding/withdrawing treatment, which courts have affirmatively held do not constitute suicide. See id. at $\S 12.02[B]$.

13. Laws whose aim is preserving sanctity of life include statutory enactments criminalizing euthanasia and court cases upholding those laws against constitutional attack. See Washington v. Glucksberg, 521 U.S. 702, 728 (1997) (holding that the U.S. Constitution does not confer the right to assisted death); Cruzan v. Dir., Mo. Dep't of Health, 497 U.S. 261, 280-81, n.8 (1990)(discussing the important state interest in preserving life); For an excellent discussion regarding the long standing tradition of aversion to suicide, see generally George P. Smith II, All's Well That Ends Well: Toward a Policy of Assisted Rational Suicide or Merely Enlightened Self-Determination?, 22 U.C. DAVIS L. REV. 275 (1989). Other state interests that are balanced against an individual's right to personal autonomy in end-of-life decisionmaking are the state's interests in protection of third parties, and maintenance of the ethics of the medical profession. See Superintendent of Belchertown State School v. Saikewicz, 370 N.E.2d 417, 424-27 (Mass. 1977). See also THE RIGHT TO DIE, supra note 10 , at $\S 5.04[B]$.

14. See THE PeW Research CTR. For the People \& THE Press, More AMERICANS DisCussing - AND PlanNing - END-Of-Life TREATMENT: Strong PUBLIC SUPPORT FOR RIGHT TO DIE 1 (2006) available at http://peoplepress.org/reports/pdf/266.pdf (a significant minority (22\%) of the people surveyed believed doctors and nurses should always do everything possible to save a patient).

15. The doctrine of informed consent is at least one basis upon which personal autonomy in the realm of medical decisionmaking is grounded. See Cruzan, 497 
choices lies the law of end-of-life decisionmaking, which has developed in the U.S. to resolve some, but not all, of the conflicts.

Conflict still persists because the tension between preservation of life and personal autonomy is not easily resolvable. Although laws appear clear on the surface, they are difficult to implement because of culture clashes and political positioning. ${ }^{16}$ The entire field of end-of-life decisionmaking law arose because preservation of life became increasingly possible through rapidly evolving medical science and technology, ${ }^{17}$ and "today's issues about forgoing life support are almost always more complex and subtle than those of the 1970s [when the legal

U.S. at 269-275. See also THE RIGHT TO DIE, supra note 10, at §2.06[A]; Alan Meisel, Physician-Assisted Suicide: Rights and Risks to Vulnerable Communities: PhysicianAssisted Suicide: A Common Law Roadmap for State Courts, 24 FORDHAM URB. L.J. 817, 845-46 (1997); LOIS SHEPHERD, If THAT Ever HAPPENS TO ME: MAKING LifE AND DEATH DECISIONS AFTER TERRI SCHIAVO 60 (2009); Kenneth W. Goodman, Terry Schaivo and the Culture Wars, in THE CASE OF TERRI SCHIAVO: ETHICS, POLITICS, AND DEATH IN THE 21 ${ }^{\text {sT }}$ CENTURY 1, 21 (Kenneth W. Goodman ed., 2009).

16. See, e.g., Robert M. Veatch, The Evolution of Death and Dying Controversies, 39 HASTINGS CTR. RPT. 16, 18 (2009) (noting that the issues raised in Schiavo "were corrupted by political and religious disputes that delayed the apparently obvious resolution of the conflict").

17. See Marilyn Webb, The Media and End-of-Life Choices and Decisions, in DECISIONMAKING NEAR THE END OF LIFE: ISSUES, DEVELOPMENTS, AND FUTURE DiRECTIONS 77, 80 (James L. Werth, Jr. \& Dean Blevins eds., 2009)

[T] he very diagnosis of PVS [Persistent Vegetative State] had only been around in medical literature for 3 years [prior to 1975]. Indeed, it had not yet been 10 years since technology had advanced far enough - through the use of emergency cardiopulmonary resuscitation (CPR) and lifeprolonging apparatuses - to allow a person to live long enough for PVS even to exist. Prior to that, we either lived, or we died

Id.;

Veatch, supra note 16, at 18 (describing evolution of end-of-life decisionmaking law). See also Kathy L. Cerminara, Three Female Faces: The Law of End-of-Life Decisionmaking in America, in DECISIONMAKING NEAR THE END OF LIFE: IsSUES, DEVElopmenTS, AND Future DiRECTIONS 95, 96 (James L. Werth, Jr. \& Dean Blevins eds., 2009) [hereinafter Cerminara, Three Female Faces]

The technological imperative encouraged extensive use of advanced machinery and chemical agents to prolong life much longer than previously had been possible. As physicians and family attempted to deal with the effects of such technological advances, 'humane decisions against resuscitative or maintenance therapy were frequently a recognized de facto response in the medical world to the irreversible, terminal painridden patient, especially with familial consent.'

Id. (citation omitted). 
principles first developed]."18 As the medical sciences advance to the level of keeping people alive in twilight-like stages of existence, the laws regarding end-of-life decisionmaking have tagged along behind scientific development. Indeed, "[i]t has been said that ' $(t)$ he law always lags behind the most advanced thinking in every area. It must wait until the theologians and the moral leaders and events have created some common ground, some consensus.'" 19 Thus, the courts and legislatures in the U.S. have been wrestling with end-of-life decisionmaking issues for the past thirty years.

\section{THE COMMON-LAW AND CONSTITUTIONAL BASES FOR END-OF- LIFE DECISIONMAKING}

U.S. end-of-life decisionmaking law developed from two primary, independent legal sources. ${ }^{20}$ The first source is the doctrine of informed consent under tort law. ${ }^{21}$ At common law, touching another person without that person's consent and without legal justification is battery.22 Thus a doctor or other medical caregiver performing any medical procedure that requires touching the patient would require the patient's informed consent, and failing to obtain informed consent would amount to the doctor committing the tort of battery on the patient. $^{23}$ Informed consent has been expanded to broadly encompass the idea that the patient must receive and understand information about the medical condition, the treatment, and the treatment's risks and benefits in order to

18. Veatch, supra note 16 , at 18.

19. See Superintendent of Belchertown State School v. Saikewicz, 370 N.E.2d 417, 423. (Mass. 1977).

20. Cerminara, Three Female Faces, supra note 17, at 97 ("both constitutional and common-law bases for the right to refuse life-sustaining treatment exist").

21. See THE RIGHT TO DIE, supra note 10, at $\S 2.06$ [A] (citing cases that discuss informed consent).

22. Cruzan v. Dir., Mo. Dep't of Health, 497 U.S. 261, 269 (1990).

23. Mohr v. Williams, 104 N.W. 12, 12, 16 (Minn. 1905); Hershley v. Brown, 655 S.W.2d 671, 676 (Mo. Ct. App. 1983). See also W. E. Shipley, Liability of Physician or Surgeon for Extending Operation or Treatment Beyond That Expressly Authorized, 56 A.L.R.2d 695, $\$ \$ 1[b], 2$ (1957). 
consent to any interference with his or her bodily integrity. ${ }^{24}$ Accordingly, informed consent means that a patient capable of making medical decisions must voluntarily consent to medical treatment after he or she is provided with enough information to make a knowledgeable decision. ${ }^{25}$

Informed consent, however, is a relatively narrow and weak basis for the right to refuse medical treatment for several reasons. First, informed consent developed from tort law, which seeks to resolve disputes between private parties with the major goal of compensating the injured party as a result of civil wrongs. The objective of tort law is not to secure fundamental rights but rather to prevent civil wrongs from happening and to compensate the injured party. ${ }^{26}$ Second, and more important, if a legislature does not agree with a judicial determination regarding the common law of informed consent, the legislature may pass a law that limits future judicial determinations in similar informed consent cases, thus changing the law. ${ }^{27}$ Third, the doctrine of informed consent, at first glance, seems to suggest that the right to refuse medical treatment does not apply to an incompetent person because informed consent requires that the patient be capable of making an informed decision. ${ }^{28}$ Yet, the right to refuse treatment is often litigated precisely because the patient suffers from a medical condition that renders him or her incapable of doing so; by necessity, the doctrine of informed consent has been extended to apply to persons who are currently incapable of making medical decisions but who have people making those decisions on their behalf. ${ }^{29}$ For these

24. Cerminara, Three Female Faces, supra note 17 , at 97-98.

25. Cerminara, Three Fernale Faces, supra note 17 , at 98.

26. See Jules Coleman, Theories of Tort Law, in THE STANFORD ENCYCLOPEDIA OF PHILOSOPHY, (Edward N. Zalta ed., Fall 2008 ed.) available at http://plato.stanford.edu/archives/fall2008/entries/tort-theories (noting that in cases of tort, courts direct people responsible for wrongful activity to either to pay damages or stop the wrongful activity).

27. Cerminara, Three Female Faces, supra note 17, at 99.

28. Cruzan v. Harmon, 760 S.W.2d 408, 417 (1988) (en banc).

29. E.g. Superintendent of Belchertown State School v. Saikewicz, 370 N.E.2d 417, 429 (Mass. 1977); Eichner v. Dillon, 420 N.E.2d 64, 70 (N.Y. 1981); In re Conroy, 486 A.2d 1209, 1229-33 (N.J. 1985); Cruzan v. Dir., Mo. Dep't of Health, 497 U.S. 261, 
reasons, those seeking to assert a right to refuse medical treatment will find a stronger basis in other legal sources (the U.S. Constitution and the Constitutions of the various states) than in the doctrine of informed consent.

Indeed, the first major reported case involving end-of-life decisionmaking recognized that the right to refuse lifesustaining treatment emanated from the constitutional right of privacy of "personal decision." ${ }^{30}$ In re Quinlan, ${ }^{31}$ a New Jersey Supreme Court case, established the right of an incompetent person in a persistent vegetative state to refuse medical treatment on the basis of both the federal and the New Jersey Constitution..$^{32}$ In that case, the father of Karen Ann Quinlan, a woman in a PVS, sought a court order granting him the express power to discontinue his daughter's ventilator support in spite of the objections of various interested parties..$^{33}$ The Quinlan court declared that the state's interests in preserving life and maintaining the ethics of the medical profession did not outweigh the patient's right to refuse treatment because of the degree of bodily invasion involved in ventilator support and the very poor prognosis of the patient. ${ }^{34}$

In securing the right to refuse treatment to a constitutional basis, the Quinlan court situated it in strong soil, more broadly and more strongly protecting the right than if it had based the

267-76 (1990).

30. In re Quinlan, 355 A.2d 647, 663 (N.J. 1976).

31. See generally id.

32. The Quinlan Court's holding that the U.S. Constitution protects the right to refuse treatment is based upon Justice Douglas's 'penumbras' of rights theory, from Griswold v. Connecticut, 381 U.S. 479, 484 (1965). Subsequent Supreme Court cases recognizing the right to privacy, however, emanate from Justice Harlan's concurrence in Griswold. In contrast to Justice Douglas, Justice Harlan argued that the right to privacy is protected by the due process clause of the Fourteenth Amendment of the U.S. Constitution as applied to the States. Even apart from this distinction, this portion of the Quinlan holding uses outdated terminology. See Cruzan v. Dir., 497 U.S. at 278 (characterizing the constitutional right that it assumed existed as a "liberty interest" rather than a privacy right).

33. Quinlan, 355 A.2d at 651. Mr. Quinlan sought appointment as his daughter's guardian in addition to seeking express power to authorize discontinuation of Karen Ann's ventilator support.

34. Id. at 663-64. 
decision on the doctrine of informed consent. No state actors, not even a legislature, can contravene rights protected under the constitution except in a constitutionally appropriate manner. ${ }^{35}$ More important, constitutional rights supersede all other sorts of law. ${ }^{36}$ The Quinlan Court's ruling thus was an auspicious beginning for champions of a right to refuse life-sustaining medical treatment, ${ }^{37}$ and many courts followed its decision to find a constitutional basis for the right. ${ }^{38}$ The U.S. Supreme Court, however, refused to rule broadly in Cruzan $v$. Director of Missouri Department of Health, ${ }^{39}$ the only case it has decided on issue of the withdrawal of treatment end-of-life decisionmaking thus far. ${ }^{40}$

Cruzan resembled Quinlan in that the case involved the parents of a young woman in a PVS seeking the courts'

35. See Marbury v. Madison, 5 U.S. 137, 176-77 (1803) (stating the Constitution is the supreme law of the land and the legislature cannot enact laws that contravene the Constitution). This principle also applies at the state level. See also Cerminara, Three Female Faces, supra note 17, at 99. See Charles H. Baron, Life and Death Decisionmaking: Judges $v$. Legislators as Sources of Law in Bioethics, $1 \mathrm{~J}$. HEALTH AND BIOMEDICAL L. 107 (2004).

36. See Baron, supra note 35, at 121 ("American Legislatures have the power to overrule common law, but they do not have the power to override constitutional rights.").

37. See Veatch, supra note 16 , at 18 (describing the case as "mov[ing] to the front and center the issues of family members' and other surrogates' involvement in decisions to forgo treatment," and serving as a basis for what became a standard approach to such issues).

38. See Superintendent of Belchertown State School v. Saikewicz, 370 N.E.2d 417, 424 (Mass. 1977); M.N. v. Southern Baptist Hosp. of Fla., Inc., 648 So.2d 769, 771 (Fla. Ct. App. 1994); In re Quackenbush, 383 A.2d 785, 789 (Morris County Ct. 1978); Leach v. Akron Gen. Med. Ctr., 426 N.E.2d 809, 813-15 (C.P.P. Div. Summit County, 1980); In re Ingram, 689 P.2d 1363, 1369-70 (Wash. 1984); In re Saenz, 728 N.W.2d 765, 775 (Wis. Ct. App. 2007). However, a few courts have found the right to refuse treatment in their states' constitutions. See Rasmussen v. Fleming, 741 P.2d 674, 682 (Ariz. 1987); In re Wendland, 28 P.3d 151, 158-59 (Cal. 2001); In re Browning, 568 So. 2d 4, 8 (Fla. 1990); In re Lawrance, 579 N.E.2d 32, 39 (Ind. 1991); Woods v. Kentucky Cabinet for Human Resources, 142 S.W.3d 24, 32 (Ky. 2004); In re Colyer, 660 P.2d 738, 742 (Wash. 1983).

39. See Cruzan v. Dir., Mo. Dep't of Health, 497 U.S. 261 (1990).

40. In Cruzan, the Court acknowledged that

[w] fe follow the judicious counsel of our decision in Twin City Bank $v$. Nebeker, where we said that in deciding 'a question of such magnitude and importance it is the [better] part of wisdom not to attempt, by any general statement, to cover every possible phase of the subject.

Id. at 277-78 (citation omitted). 
authorization to withdraw life-prolonging treatment. ${ }^{41}$ The parents of Nancy Cruzan asked the U.S. Supreme Court to review the Missouri Supreme Court's decision denying their request to withdraw Ms. Cruzan's medically supplied hydration and nutrition. The Missouri Supreme Court had framed the issue before it in the following manner: "May a guardian order that food and water be withheld from an incompetent ward who is in a persistent vegetative state but who is otherwise alive within the meaning of [Missouri statute] and not terminally ill?"42 Answering this question in the negative, the Missouri Supreme Court applied the Missouri living will statute and interpreted the clear and convincing evidentiary standard set forth in the statute as requiring that the evidence presented must demonstrate the incompetent person's prior, actual, expressed wishes. Such a high procedural and evidentiary standard applied, according to that court, because Missouri's legislature had expressed a desire to strongly favor the preservation of life. ${ }^{43}$ The court denied Ms. Cruzan's parents' request to withdraw life-prolonging treatment because they had not provided proof that Ms. Cruzan previously had stated that she wanted medically supplied nutrition and hydration withdrawn if she ever entered a PVS. ${ }^{44}$

The Missouri court rested its decision on a number of grounds. First, it reasoned that a patient could not authorize withdrawal of treatment under the doctrine of informed consent because it was impossible for a patient to act in an informed manner to future hypothetical circumstances. ${ }^{45}$ It also declined

41. Ms. Cruzan's parents sought "a court order directing the withdrawal of their daughter's artificial feeding and hydration equipment" rather than withdrawal of ventilator support as in Quinlan. Id. at 265.

42. Cruzan v. Harmon, 760 S.W.2d 408, 412 (1988) (en banc).

43. Id. at $419-20$.

44. Id. at 424 .

45. The court reasoned that it would be "definitionally impossible for a person to make an informed decision - either to consent or to refuse - under hypothetical circumstances" because the three factors required for informed consent were not present. Id. at 417 (listing the following as requirements: a patient with "capacity to reason and make judgments," a "decision . . made voluntarily and without coercion," and a patient having "a clear understanding of the risks and benefits of 
to interpret the Missouri state constitution to include a broad right of privacy that would confer the right to refuse treatment. ${ }^{46}$ Moreover, it was skeptical about the existence of a federal constitutional right to privacy protecting a right to refuse medical treatment. ${ }^{47}$ Finally, it declared that " $[\mathrm{b}] \mathrm{road}$ policy questions bearing on life and death are more properly addressed by representative assemblies," i.e. the legislature, than the courts. $^{48}$

It was against this backdrop that the United States Supreme Court had to decide whether the Missouri court's strict application of such a demanding standard of proof violated Ms. Cruzan's liberty interest in refusing treatment under the U.S. Constitution. In ruling that the Missouri court's decision did not violate the U.S. Constitution, the United States Supreme Court went on to state that "logic of the [constitutional cases previously cited in the opinion] would embrace" a competent person's liberty interest in refusing medical treatment, including medically supplied nutrition and hydration, but it saw no need to hold to that effect. ${ }^{49}$ Instead, the Court assumed that "the United States Constitution would grant a competent person a constitutionally protected right to refuse lifesaving hydration and nutrition."50 The Court also avoided the issue of whether an incompetent person has the same right to refuse treatment. ${ }^{51}$ Instead, the Court narrowly decided that Missouri's requirement "that evidence of the incompetent's wishes as to the withdrawal of treatment be proved by clear and convincing evidence" did not violate the federal Constitution. ${ }^{52}$

the proposed treatment alternatives or nontreatment, along with a full understanding of the nature of the disease and the prognosis"). Id.

46. Id. at $417-18$.

47. Id. at 418.

48. Id. at 426 .

49. Cruzan v. Dir., Mo. Dep't of Health, 497 U.S. 261, 279 (1990).

50. Id. Later, the Court indicated that this ruling "strongly suggested" that a constitutional right exists. See Washington v. Glucksberg, 521 U.S. 702, 720 (1997); Vacco v. Quill, 521 U.S. 793, 807 (1997); see generally THE RIGHT TO DIE, supra note 10 , at $\S 2.03[\mathrm{~A}][1],[2]$.

51. Cruzan v. Dir., 497 U.S. at 280.

52. See id. 


\section{MEDICALLY SUPPLIED NUTRITION AND HYDRATION}

In addition to avoiding the issue of whether an incompetent person has a constitutional right to refuse treatment, Cruzan's majority opinion did not expressly decide whether medically supplied nutrition and hydration constitute medical treatment a patient can refuse. It did, however, imply as much by stating that "for purposes of this case, we assume that the United States Constitution would grant a competent person a constitutionally protected right to refuse lifesaving hydration and nutrition." 53 Moreover, five of the justices (O'Connor, Brennan, Marshall, Blackmun, and Stevens), in their respective concurrences and dissents, agreed that medically supplied nutrition and hydration constitutes medical treatment that patients may refuse like any other treatment. In her concurring opinion, Justice $\mathrm{O}^{\prime}$ Connor stated that "[a]rtificial feeding cannot readily be distinguished from other forms of medical treatment." ${ }^{54}$ Thus, she concluded that "the liberty guaranteed by the Due Process Clause must protect... an individual's deeply personal decision to reject medical treatment, including the artificial delivery of food and water." 55 Likewise, Justice Brennan's dissent (joined by Justices Marshall and Blackmun) emphatically declared that "[n]o material distinction can be drawn between ... artificial nutrition and hydration ... and any other medical treatment." ${ }^{156}$ Justice Stevens's dissent implicitly agreed with this conclusion as well, when he declared that Ms. Cruzan's best interest would be served "by allowing her guardians to exercise her constitutional right to discontinue medical treatment" with full knowledge that the treatment in question was medically supplied nutrition and hydration. ${ }^{57}$

In contrast, the majority opinion of the Missouri Supreme Court had viewed medically supplied hydration and nutrition

53. Id. at 279 .

54. Id. at 288 .

55. Id. at 289 .

56. Id. at 307 .

57. Id. at 331 . 
differently. Rather than accepting the medical convention ${ }^{58}$ as a legal fact, the majority opinion of the Missouri Supreme Court questioned the medical convention, even boldly asserting that "common sense tells us that food and water do not treat an illness, they maintain life."59 This portion of the opinion is essentially unsupported, for, although the court declared that "[t]here is substantial disagreement... among physicians and ethicists [that medically supplied hydration and nutrition are medical treatments]," the footnote supporting that declaration points to the very medical conclusion with which the Court disagreed, an opinion of the Council on Ethical and Judicial Affairs of the American Medical Association stating that medically supplied hydration and nutrition are medical treatment. ${ }^{60}$ Unlike the Missouri court in Cruzan, the majority of other courts have held that medically supplied nutrition and hydration are medical treatments that patients can refuse, even when incompetent. ${ }^{61}$ Yet this issue remains a point of contention; it would re-surface approximately 15 years later, when disability rights and pro-life groups in Florida argued that medically supplied hydration and nutrition constituted everyday care that patients could not refuse.

\section{The Schiavo Litigation and the Politics of END-OF-Life DECISIONMAKING LAW IN THE U.S.}

In February of 1990, Theresa Marie Schiavo suffered a cardiac arrest that left her in a persistent, or permanent, vegetative state

58. The Council of Ethical and Judicial Affairs of the AMA (the CEJA) considers medically supplied nutrition and hydration to be medical treatment that a patient may refuse. See AM. MED. ASS'N COUNCIL ON ETHICAL AND JUDICIAL AfFairs, CODE of Medical ETHICS: CURRENT Opinions With ANNOTATIONS 2.20 at 65 (2002-2003 ed.); Cruzan v. Harmon, 760 S.W.2d 408, 423 n.18 (1988) (en banc) (citing then-current CEJA opinion to the same effect). See also THE RIGHT TO DIE, supra note 10 , at $\S 6.03[\mathrm{G}][4]$.

59. Cruzan v. Harmon, 760 S.W.2d at 423. In making this statement, the court seemed to adopt the views stated in the briefs of the Missouri Citizens for Life, the Association for Retarded Citizens of the United States and the Ethics and Advocacy Task Force of the Nursing Home Action Group. Id. at 423 n.19.

60. Id. at 423 n. 18 .

61. See THE RIGHT TO DIE, supra note 10 , at $§ 6.03[\mathrm{G}]$. 
(PVS).62 Unlike Quinlan, Cruzan, and Englaro, Schiavo raised no unsettled issues. To the contrary, the case presented well-settled issues under Florida laws that permitted (and still permit) withholding or withdrawal of life-sustaining treatment when a patient is in a PVS.63 Also distinct from Quinlan, Cruzan and Englaro, in which the State, in some form, protested the withdrawal of treatment, ${ }^{64}$ Schiavo involved a dispute solely between private parties, one of whom sought out the courts for resolution. In that litigation, Ms. Schiavo's husband, Michael Schiavo, and her parents, Robert and Mary Schindler, sharply disagreed over whether to authorize withdrawal of medically supplied nutrition and hydration after Ms. Schiavo had been in a PVS for eight years.

Although the Schiavo litigation was not the first case in which family members went to court concerning the refusal or withdrawal of life-sustaining care, ${ }^{65}$ the litigation proved to be quite public and controversial. ${ }^{66}$ It lasted for more than seven years, with its final months memorialized in multiple media

62. While legal sources use the terminology "persistent vegetative state," neurologists suggest that it is most appropriate to recognize that, after some time, a persistent vegetative state transforms into a permanent vegetative state, from which a patient is extremely unlikely to regain consciousness. See Kathy L. Cerminara, Musings on the Need to Convince Some People With Disabilities That End-Of-Life Decisionmaking Advocates Are Not Out to Get Them, 37 LOY. U. CHI. L.J. 343, 352 (2006) [hereinafter Cerminara, Musings].

63. FLA. STAT. § 765.302(1) (2009) ("Any competent adult may, at any time, make a living will or written declaration and direct the providing, withholding, or withdrawal of life-prolonging procedures in the event that such person . . . is in a persistent vegetative state.").

64. Of additional special interest in terms of a state's protesting withdrawal of treatment are the Sylvia Pouliot case and the gubernatorial intervention in the Hugh Finn case. See Alicia R. Ouellette, When Vitalism is Dead Wrong: The Discrimination Against and Torture of Incompetent Patients by Compulsory LifeSustaining Treatment, 79 IND. L.J. 1, 13-21 (2004) (discussion of Pouliot); See Blouin v. Spitzer, 2001 U.S. Dist. LEXIS 18243 (N.D. N.Y. 2001) (aftermath of Pouliot); See Gilmore v. Finn, 527 S.E.2d 326 (Va. 2000) (aftermath of Finn); Cerminara, Musings, supra note 62, at 366-67 (discussion of Finn).

65. See THE RIGHT TO DIE, supra note 10, at $\S 3.18$.

66. See, e.g., Kathy L. Cerminara, Collateral Damage: The Aftermath of the Political Cultural Wars in Schiavo, 29 W. NEW ENG. L. REV. 279, 279-80 n. 2-6 (2007) [hereinafter Cerminara, Collateral Damage] (listing numerous articles and books published just within the year after Ms. Schiavo's death). 
accounts. ${ }^{67}$

Furthermore, Schiavo added a political dimension to a dispute that normally would have been resolved privately or through the judicial system. The disagreement in Schiavo would ultimately involve not only the Florida courts, but also the Florida legislature and executive branch, plus all branches of the federal government. ${ }^{68}$ Although Schiavo did not affect end-of-life decisionmaking law in Florida, it had a major impact on the politics of end-of-life decisionmaking law and, as such, influenced the Italian political response to Englaro. ${ }^{69}$

\section{ADVANCE DIRECTIVES IN THE UNITED STATES: LIVING WILLS VERSUS HEALTH CARE POWERS OF ATTORNEY}

Ms. Schiavo's family members did not have the benefit of an advance directive as they tried to discern whether she would have wanted to receive medically supplied nutrition and hydration as she lay in a PVS. ${ }^{70}$ Advance directives "are mechanisms by which competent individuals plan for medical decisionmaking at a future time when they might no longer possess decisionmaking capacity."71 The term "advance directive" can signify many different things. The term can refer to a person's oral or written statements regarding the course of treatment to be effectuated under certain conditions. It also can refer to instruments containing such instructions such as

67. See Robert M. Walker \& Jay Black, Terri Schiavo and Televised News: Fact or Fiction?, in THE CASE OF TERri SCHIAvo: ETHICS, POLITICS, AND DEATH IN THE 21ST CENTURY 210, (Kenneth Goodman ed., 2010).

68. See Cerminara, Long Road to Peace, supra note 3, at 101. See also Cerminara, Collateral Damage, supra note 66, at 282-88.

69. When the Schiavo case ended, the Englaro case was far from being resolved, the two were quite similar, and references to the Schiavo case emerged in the political struggles following one of the higher-level rulings in Englaro. See infra p. 328-60; see also Federico Gustavo PizZetti, Alle Frontiere Della vita: IL Testamento Biologico tra Valori Costituzionali e Promozione della PERSONA (2008).

70. In re Schiavo, No. 90-2908GD-003, slip op. at 4 (Fla. Pinellas County Ct. Feb, 11, 2000), available at http://www.miami.edu/ethics/schiavo/pdf_files/021100Trial_Ct_Order_0200.pdf

71. THE RIGHT TO DIE, supra note 10 , at $\S 7.01[\mathrm{~A}]$. 
instructional directives (commonly referred to as living wills) or proxy directives (referred to by a variety of names, including health care powers of attorney). A living will is a written instrument that provides instructions to health care providers regarding the types of medical care individuals wish to receive under certain stated conditions. ${ }^{72}$ A health care power of attorney is an instrument pursuant to which an individual appoints another person, generally referred to as a proxy, to make health care decisions in the event that he or she lacks the capacity to make medical treatment decisions. ${ }^{73}$

For a long time after Quinlan was decided in 1976, considerable uncertainty existed concerning the validity and enforceability of advance directives. ${ }^{74}$ California was the first state to enact a living will statute in 1976, in an attempt to prevent the type of litigation that occurred in Quinlan. ${ }^{75} \mathrm{By}$ expressly legitimizing living wills, the California statute provided a mechanism for competent individuals to plan for the type of treatment they wished to receive in the event that they lacked the capacity to decide for themselves. Somewhat later, state legislatures also began to enact health care power of attorney statutes, granting individuals the right to appoint proxies to make medical decisions on their behalf. ${ }^{76}$ Although Ms. Schiavo could have designated a health care proxy to make health care decision for her, ${ }^{77}$ or left a living will specifying her

72. Id. at $\$ 7.01[\mathrm{~B}][3]$.

73. Id. at $\$ 7.01[\mathrm{~B}][4]$.

74. Id. at $\S 7.02[\mathrm{~A}]$.

75. Id. at $\$ 7.02[\mathrm{D}]$.

76. Id. at $\S 7.01[\mathrm{~B}]$.

77. Fla. Stat. § 765.202 (2008). Florida uses the term "surrogate", rather than "proxy" to identify a person an individual selects to make medical decisions on his or her behalf. In contrast, other states use the term "surrogate" to identify a person who acquires decisionmaking authority by operation of law. A "proxy" decision maker in Florida refers to a person who has the authority, acquired by law, to make medical decisions for an incapacitated individual without the individual in question having appointed him or her as such However, other states use the term "proxy" to refer to a person whom an incapacitated individual selects to make medical decision through advance directives. See THE RIGHT TO DIE, supra note 10, at $\$ 7.01[B][4],[6]$.

For the sake of clarity, this article will use the term "proxy" to refer to individuals 
wishes with respect to her end-of-life care, ${ }^{78}$ she did not. ${ }^{79}$ By the time the Schiavo litigation began in 1998, both types of advance directives were recognized and enforceable in Florida. ${ }^{80}$

\section{SURROGATE ${ }^{81}$ DECISIONMAKING: SUBSTANTIVE STANDARD FOR DECISIONMAKING VERSUS CLEAR AND CONVINCING EVIDENTIARY STANDARD}

Despite the fact that Ms. Schiavo had neither appointed a health care surrogate nor left a living will, Florida law still allowed a health care surrogate ${ }^{82}$ to elect to withhold or withdraw life sustaining treatment for her if clear and convincing evidence indicated that that she would have chosen to do so. ${ }^{83}$ Florida Statute $\S 765.401(1)$ lists, in order of priority, persons who may act as surrogate decision makers when a patient has neither a living will nor a health care power of attorney. ${ }^{84}$ As Ms. Schiavo's legal guardian, Mr. Schiavo was first in line to make health care decisions for her. ${ }^{85}$ As her

appointed by the incapacitated individuals to make health care decisions on their behalf through advance directives, while the term "surrogate" will be used to refer to persons who acquire medical decisionmaking authority through operation of law, rather than through advance directives.

78. Fla. Stat. $\$ 765.301-308$ (2008).

79. In re Guardianship of Schiavo, No. 90-2908GD-003, slip op. at 4 (Fla. Pinellas County Ct. Feb, 11, 2000), available at http://www6.miami.edu/ethics/ schiavo/pdf_files/021100-Trial_Ct_Order_0200.pdf.

80. FLA. STAT. $§ 765.302$ (1997) recognizes living wills, while FLA. STAT. § 765.202 (1997) recognizes health care surrogate designations.

81. In this context, the term "surrogate" refers to a person who makes health care decisions on behalf of another when the person acquires the authority to act through operation of law, rather than by advance directive. See supra note 77 . See also THE RIGHT TO DIE, supra note 10, at $\S 7.01[\mathrm{~B}][4]$, [6].

82. THE RIGHT TO DIE, supra note 10 , at $\S 7.01[B][4]$, [6]. See also supra note 77 (describing Florida's terminology, i.e. proxy versus surrogate).

83. FLA. STAT. § 765.401(3) (1997).

84. Florida is not unique in having this type of statute. The primary purpose for having this type of statute is to "make clear. . that the customary medical professional practice of using family members to make decisions for patients who lack decisionmaking capacity and who lack advance directives is legally valid, and that ordinarily judicial proceedings need not be initiated for the appointment of a guardian." THE RIGHT TO DIE, supra note 10, at §8.01. In Schiavo, Mr. Schiavo had already been appointed her legal guardian, several years before the question of withdrawing her medically supplied nutrition and hydration arose.

85. FLA. STAT. § 765.401(1)(a) (1997). 
spouse, Mr. Schiavo also was second in line to make health care decisions on her behalf. ${ }^{86}$

Like many other surrogate decisionmaking statutes, the Florida statute accords the surrogate decision maker broad discretion to make health care decisions on behalf of the patient. ${ }^{87}$ In matters relating to withholding or withdrawing lifeprolonging procedures, the Florida statute requires clear and convincing evidence that a decision to withhold or withdraw is one the patient would have made had the patient been competent to make the determination. ${ }^{88}$ Thus, the statue requires the surrogate to meet two distinct standards in making the decision to withhold or withdraw life-prolonging procedures for the patient: a substantive decisionmaking standard and an evidentiary standard.

Florida has chosen substituted judgment as the applicable substantive decisionmaking standard. ${ }^{89}$ It requires the surrogate to make health care decisions based on what the surrogate "reasonably believes the patient would have made under the circumstances." 90 Determining a patient's wishes in accordance with the substituted judgment standard is a holistic enterprise; the surrogate decision maker is not limited to examining a living will or other instructional document. Rather, the task when using a substituted judgment standard of decisionmaking is

to determine what the patient would have wanted to do had he or she considered the question at hand. Evidence of precisely what the patient would have wanted, in the form of written advance directives or oral statements effectively constituting advance directives, is useful, but it is not required. A decision made pursuant to a substituted judgment standard can be determined by asking what a patient would have

86. FLA. STAT. § 765.401(1)(b) (1997).

87. THE RIGHT TO DIE, supra note 10 , at $\S 8.07$.

88. FLA. STAT. $§ 765.401(3)$ (1997) (when there is no indication of what the patient would have chosen, the statute allows the surrogate to decide to withdraw or withhold life-prolonging treatment if the decision is in the patient's best interest.)

89. See FLA. STAT. § 765.401(2) (1997).

90. Id. For a discussion of other substantive decisionmaking standards used by various jurisdictions, see THE RIGHT TO DIE, supra note 10, at $§ 4.02[\mathrm{~A}]$. 
wanted based on that patient's values, beliefs, and attitudes..$^{91}$

This is distinct from the clear and convincing evidentiary standard. A clear and convincing evidence evidentiary standard requires the surrogate to provide enough evidence that

produces in the mind of the trier of fact a firm belief or conviction as to the truth of the allegations sought to be established, evidence so clear, direct and weighty and convincing as to enable [the factfinder] to come to a clear conviction, without hesitancy, of the truth of the precise facts in issue. ${ }^{92}$

Many jurisdictions have adopted a clear and convincing standard of proof in end-of-life cases, ${ }^{93}$ at least in part because "particularly important personal interests are at stake." ${ }^{94}$ In Florida, had Ms. Schiavo completed a living will, that living will presumptively would have constituted clear and convincing evidence of her wishes. ${ }^{95}$ Because she did not, however, the initial dispute in Schiavo centered on whether Ms. Schiavo would have wanted to be kept alive through medically supplied nutrition and hydration despite her condition.

\section{THE LITIGATION}

Sometime after Ms. Schiavo entered a PVS, the court appointed Mr. Schiavo, her husband, as her guardian, a determination Ms. Schiavo's parents, the Schindlers, did not contest. Although Mr. Schiavo and the Schindlers initially agreed on Ms. Schiavo's medical care, rifts began to develop. In July of 1993, "the Schindlers unsuccessfully sought to remove

91. Kathy L. Cerminara, Tracking the Storm: The Far-Reaching Power of the Forces Propelling the Schiavo Cases, 35 STETSON L. REV. 147, 165 (2005) [hereinafter, Cerminara, Tracking the Storm] (footnotes omitted).

92. In re Jobes, 529 A.2d 434, 441 (N.J. 1987) (quoting State v. Hodge, 471 A.2d 389,393 (N.J. 1984)) (citations omitted). See In re Guardianship of Browning, 543 So. 2d 258, 273 (Fla. Dist. Ct. App. 1989) (adopting this definition of clear and convincing standard).

93. THE RIGHT TO DIE, supra note 10 , at $\S 3.27[\mathrm{~A}]$.

94. Matter of Storar, 420 N.E.2d 64, 72 (N.Y. 1981) (citing Addington v. Texas, 441 U.S. 418,424 (1979)).

95. In re Guardianship of Browning, 568 So. 2d 4, 16 (Fla. 1990). 
Mr. Schiavo from his court-appointed guardianship of Mrs. Schiavo." 96 In 1998, Mr. Schiavo petitioned a Florida court to decide whether Ms. Schiavo would want to be kept alive on the percutaneous endoscopic gastrostomy (PEG) tube. ${ }^{97}$ Under Florida law, Mr. Schiavo, acting as the guardian, could have made this decision himself, or he could have asked the court to make this determination for him;98 he chose to ask the court to decide because he "recognized that he and the Schindlers would disagree on whether to remove [Ms. Schiavo's] PEG tube." 99

Before issuing a decision, the court appointed a guardian ad litem for Ms. Schiavo. By the time the litigation was over, in fact, three guardians ad litem would examine her case. One of those three concluded that both Mr. Schiavo and the Schindlers may have been influenced by a medical malpractice award that resulted from a lawsuit over her pre-cardiac arrest care. ${ }^{100}$ That guardian ad litem believed that Mr. Schiavo's conflict of interest, coupled with his expression of a desire to withdraw treatment only after the malpractice award, so colored his testimony that he could not satisfy the clear and convincing evidentiary standard in showing that Ms. Schiavo would have wanted her PEG tube withdrawn. Although discounted by the trial court hearing the case, ${ }^{101}$ and indeed although no court ever found a conflict of interest in Schiavo, ${ }^{102}$ this guardian ad litem's opinion highlights one stark contrast with the situation in Englaro. In

96. Cerminara, Long Road to Peace, supra note 3, at 103. See also Cerminara, Key Events, supra note 5; See MARY SCHINDLER \& AND ROBERT SCHINDLER, A LIFE THAT MATTERS: THE LEGACY OF TERRI SCHIAVO - A LESSON FOR US ALL 58-59 (2006) (describing hiring a lawyer who "went after Michael's guardianship of Terri"); MiCHAEL SCHIAVO WITH MICHAEL HIRSCH, TERRI: THE TRUTH 89 (2006) (describing initial Schindler v. Schiavo pleadings, filed on July 29, 1993).

97. A PEG tube is a method by which liquid nutrition and hydration are administered to patients. See Cerminara, Tracking the Storm, supra note 91, at 149 n.18.

98. See In re Guardianship of Browning, 568 So. 2d 4, 16 (Fla. 1990). See also Cerminara, Tracking the Storm, supra note 91, at 161-62.

99. Cerminara, Tracking the Storm, supra note 91 , at 162.

100. In re Guardianship of Schiavo, No. 90-2908GD-003, slip op. at 2-4 (Fla. Pinellas County Ct. Feb. 11, 2000).

101. Id. See also Cerminara, Tracking the Storm, supra note 91, at 161.

102. See Cerminara, Tracking the Storm, supra note 91, at 161. 
Englaro, no financial conflict of interest presented itself and the sole Italian-trial-court-appointed guardian ad litem agreed that Ms. Englaro's PEG tube should be removed.

On February 11, 2000, the trial court approved Mr. Schiavo's request that Ms. Schiavo's physicians withdraw the PEG tube providing her with medically supplied nutrition and hydration. First, the court determined "beyond all doubt" that Ms. Schiavo was in a persistent vegetative state as defined in the Florida statute. ${ }^{103}$ Second, the court found that Ms. Schiavo would have wished to have her PEG tube withdrawn under the circumstances, in the process addressing all relevant information (including explanations as to why it was discounting some portions of evidence while crediting others). ${ }^{104}$

The Schindlers appealed this decision on three bases. First, the Schindlers contended that the trial court should have appointed another guardian ad litem to represent Ms. Schiavo in the proceeding because of Mr. Schiavo's financial conflict of interest. ${ }^{105}$ Second, they argued that the trial court had made its decision based on Ms. Schiavo's best interest rather than determining what Ms. Schiavo would have wanted in accordance with the substituted judgment standard of decisionmaking. ${ }^{106}$ Finally, they argued that the evidence presented about Ms. Schiavo's wishes during trial did not meet the "clear and convincing" evidentiary standard. ${ }^{107}$

In January 2001, the Florida Second District Court of Appeal upheld the trial court's ruling that permitted the removal of Ms. Schiavo's PEG tube. The appellate court dismissed the

103. In re Guardianship of Schiavo, No. 90-2908GD-003, slip op. at 6 (Fla. Pinellas County Ct. Feb. 11, 2000) (order granting removal of Ms. Schiavo's PEG tube).

104. Id. at 9 .

105. In re Guardianship of Schiavo, 780 So. $2 d$ 176, 178 (Fla. Dist. Ct. App. 2001) [hereinafter Schiavo I], rev. denied, 789 So. 2d 348 (Fla. 2001).

106. This argument rested on the court's admission of certain evidence regarding the results of certain social science survey of people's desires about endof-life decisionmaking. Schiavo I, 780 So. $2 \mathrm{~d}$ at 179 . See also Cerminara, Tracking the Storm, supra note 91 , at $165-68$.

107. Shiavo I, 780 So. $2 \mathrm{~d}$ at 179. 
Schindler's first argument because Mr. Schiavo was not serving as the decision-maker in the proceeding but rather was asking the court to make the decision. ${ }^{108}$ Second, the appellate court concluded that the trial court properly made a decision based on what Ms. Schiavo would have wanted to have done. ${ }^{109}$ Finally, it determined that the trial court had sufficient evidence to decide that Ms. Schiavo would have wanted the PEG tube withdrawn. ${ }^{110}$ The appellate court noted that while the clear and convincing evidentiary standard is very high, the standard "permits a decision in the face of inconsistent or conflicting evidence."111 It concluded that "[t]he evidence [was] overwhelming that [Ms. Schiavo was] in a permanent or persistent vegetative state."112 The Florida Supreme Court denied review of the Schindlers' appeal of the appellate court's decision. ${ }^{113}$

Ms. Schiavo's PEG's tube was removed in April 2001, ${ }^{114}$ but was reinserted after the Schindlers filed a new lawsuit, resulting in yet another trip up the judicial ladder and back down in Florida. Several judicial opinions later, still on the losing end, the Schindlers would shift their legal argument and cause a political storm surrounding Ms. Schiavo's life and death.

\section{THE POLITICAL FUROR}

Well into the litigation, the Schindlers argued for the first time that Ms. Schiavo was not in a persistent vegetative state and that, rather than refusing medically supplied nutrition and hydration, she would have chosen a medical procedure that could improve her medical condition. ${ }^{115}$ After still more judicial

108. Id. at 178 .

109. Id. at 179.

110. Id.

111. Id.

112. Id. at 177.

113. In re Guardianship of Schiavo, 789 So. $2 \mathrm{~d} 348$ (Fla. 2001).

114. In re Guardianship of Schiavo, 792 So. 2d 551, 555 (Fla. Dist. Ct. App. 2001) [hereinafter Schiavo II].

115. In re Guardianship of Schiavo, 800 So. 2d 640, 643-44 (Fla. Dist. Ct. App. 
proceedings, the trial court once again authorized the removal of Ms. Schiavo's PEG tube. ${ }^{116}$ The Schindlers' unsuccessful appeal ${ }^{117}$ of this trial court ruling attracted amici curiae briefs from representatives of various special interest groups, many of which focused on disability rights and vitalist causes. Schiavo became the bulls-eye in the target of interest-group politics.

At this point, the litigation transformed from a dispute between private parties to one that involved a multitude of special interest groups and their supporters, nearly causing a constitutional crisis in the state of Florida. News media coverage of the Schiavo case added to the political pressure on Governor Jeb Bush and the Florida Legislature to intervene. Thus, in October 2003, the Florida Legislature enacted a law specifically addressing Ms. Schiavo's case, which became known as "Terri's Law," authorizing Governor Bush to issue an executive order requiring reinsertion of Ms. Schiavo's PEG tube. ${ }^{118}$ Mr. Schiavo challenged "Terri's law," arguing that the law was unconstitutional, and the Supreme Court of Florida agreed, holding that "Terri's Law" violated the separation of powers doctrine of the Florida Constitution. ${ }^{119}$ The political response to Englaro in Italy would similarly create a constitutional crisis of a different dimension there.

The political pressure not only affected Florida, but also extended to the national level, driving the U.S. Congress to take action on the Schiavo case. The U.S. House of Representatives

2001) [hereinafter Schiavo III].

116. In re Guardianship of Schiavo, 851 So. 2d 182, 185 (Fla. Dist. Ct. App. 2003) [hereinafter Schiavo IV].

117. Schiavo IV, 851 So. $2 \mathrm{~d}$ at 187.

118. 2003 Fla. Laws Ch. 418, $\S 1$ (reprinted in full in Bush v. Schiavo, 885 So. $2 \mathrm{~d}$ 321, 328-29 (Fla. 2004)) (held unconstitutional in Bush v. Schiavo, 885 So. 2d 321, 337 (Fla. 2004), cert. denied, 543 U.S. 1121, 125 S. Ct. 1086 (2005)). See generally Barbara A. Noah, Politicizing the End of Life: Lessons from the Schiavo Controversy, 59 U. MIAMI L. REV. 107 (2005).

119. Bush v. Schiavo, 855 So. 2d 321, 337 (Fla. 2004). Specifically, the court held that the law encroached upon the judiciary's power to decide cases. Id. at 332. Furthermore, the court held that the legislature had unconstitutionally delegated its legislative power to the governor by granting him unrestricted power to issue a stay without defining standards to follow in deciding when and whether to issue or end the stay. $I d$. at 336 . 
Committee on Government Reform unsuccessfully asked the Florida trial court to stay the order authorizing removal of Ms. Schiavo's PEG tube. By contrast, Congress successfully passed Senate Bill $686,{ }^{120}$ which provided federal court jurisdiction

to hear, determine, and render judgment on a suit or claim by or on behalf of Theresa Marie Schiavo for the alleged violation of any right of Theresa Marie Schiavo under the Constitution or laws of the United States relating to the withholding or withdrawal of food, fluids, or medical treatment necessary to sustain her life. ${ }^{121}$

President Bush signed the bill into private law on March 21, 2005. ${ }^{122}$ More litigation ensued, ${ }^{123}$ and it appeared at one point as if the governor of Florida would send the Florida Department of Children and Families into Ms. Schiavo's hospice to seize and "rescue" her, ${ }^{124}$ but the Schindlers were unable to have Ms.

120. Senate Bill 686 was a private bill passed for the relief of the parents of Theresa Marie Schiavo. See An Act For the relief of the parents of Theresa Marie Schiavo, S. 686, 109th Cong. (2005), available at http://www6.miami.edu/ethics /schiavo/pdf_files/032005-USSenate_Compromise_in_Schiavo.pdf.

A private bill provides benefits to specified individuals (including corporate bodies). Individuals sometimes request relief through private legislation when administrative or legal remedies are exhausted. . If a private bill is passed in identical form by both houses of Congress and is signed by the president, it becomes a private law.

Legislation, Laws, and Acts, U.S. SENATE, http://www.senate.gov/legislative/ common/briefing/leg_laws_acts.htm (last visited Apr. 9, 2011).

121. See An Act For the relief of the parents of Theresa Marie Schiavo, supra note 120 .

122. Schiavo ex rel. Schindler v. Schiavo, 357 F. Supp. 2d 1378, 1382 (M.D. Fla.), aff'd, 403 F.3d 1223, 1229 (11th Cir.), reh'g en banc denied, 403 F.3d 1261, 1261 (11th Cir.), stay denied, 544 U.S. 945 (2005). See Cerminara, Key Events, supra note 5.

123. Upon enactment of this law, the Schindlers filed suit in the United States District Court for the Middle District of Florida and requested the judge to order reinsertion of the PEG tube pending the federal claims asserted. The federal district court judge refused to grant the preliminary injunction, reasoning that the Schindlers were unlikely to succeed on any of the federal claims asserted. See Schiavo ex rel. Schindler v. Schiavo, 357 F. Supp. 2d 1378, 1388 (M.D. Fla.), aff'd, 403 F.3d 1223 (11th Cir.), reh'g en banc denied, 403 F.3d 1261 (11th Cir. en banc), stay denied, 125 S. Ct. 1692 (2005). The U.S. Court of Appeals for the Eleventh Circuit and the U.S. Supreme Court refused to reverse the district court's decision. See also Schiavo ex rel. Schindler v. Schiavo, 358 F. Supp. 2d 1161, 1163 (M.D. Fla.), aff'd, 403 F.3d 1289, 1296 (11th Cir.), reh'g en banc denied, 404 F.3d 1270, 1271 (11th Cir. en banc), reh'g denied, 404 F.3d 1282, 1283 (11th Cir.), stay denied, 544 U.S. 957 (2005).

124. Cerminara, Long Road to Peace, supra note 3, at 110. 
Schiavo's PEG tube reinserted. She passed away on March 31, $2005 .{ }^{125}$

Although Schiavo did not change the end-of-life decisionmaking laws in Florida, Schiavo's impact on the politics of end-of-life decisionmaking law cannot be overstated. ${ }^{126}$ Issues that were once settled became unsettled during the political upheaval that occurred during the Schiavo litigation. ${ }^{127}$ In addition, subsequent events in Italy indicate that Schiavo's political impact traveled across the Atlantic and affected yet another end-of-life decisionmaking case there.

\section{THE ENGLARo Litigation AND THE Politics OF END-OF-LifE DECISIONMAKING LAW IN ITALY}

On January 18, 1992, approximately two years after Ms. Schiavo entered a PVS, Eluana Englaro was involved in an automobile accident in Italy that eventually left her in a PVS. ${ }^{128}$ Four years after the accident, the Tribunale Lecco (the Trial Court) declared Ms. Englaro incompetent and appointed her father, Beppino Englaro (Mr. Englaro), as her guardian. ${ }^{129}$ For the next seventeen years, Mr. Englaro would litigate to enforce what he considered to be his daughter's wish to discontinue life-prolonging treatment. Indeed, the length and path of Eluana Englaro's litigation bears a striking resemblance to those of Terri Schiavo's cases. But instead of the litigation resolving a dispute between two private parties like Schiavo, Englaro involved the state

125. See Cerminara, Key Events, supra note 5.

126. See Cerminara, Collateral Damage, supra note 66, at 279-93; Cerminara, Tracking the Storm, supra note 91, at 147-48.

127. Lois Shepherd, Terri Schiavo: Unsettling The Settled, 37 LOY. U. CHI. L.J. 297, 299301 (2006) (noting that the Schiavo cases had raised questions around three topics: "the role of surrogate decision-making in cases of permanent vegetative state; the relevance of the physical condition of the patient in questions of treatment refusal; and the significance of artificial nutrition and hydration as the kind of treatment refused").

128. Corte App. Milano, Sect. I Civ., 9 July 2008, g. 88/2008, 2 [hereinafter Englaro IX] available at http://www.nsulaw.nova.edu/library_tech/library /resources/local/milan/index.cfm.

129. Id. 
protesting the refusal of treatment. In fact, Englaro is a closer comparison to Quinlan than Schiavo, both for that reason and because Englaro represents Italy's first major decision on the issue of withdrawing life sustaining treatment.

\section{THE LITIGATION}

In January of 1999, the Trial Court rejected Mr. Englaro's request to discontinue Ms. Englaro's medically supplied hydration and nutrition. The Trial Court held that Mr. Englaro's request was incompatible with Article 2 of the Italian Constitution, which the court interpreted as providing absolute and imperative protection of the right to life. ${ }^{130} \mathrm{Mr}$. Englaro appealed the Trial Court's decision to the Corte d'Appello di Milano (Court of Appeal). ${ }^{131}$ In December of that year, the Court of Appeal issued a decree indicating that it would not hear the appeal. It disposed of the case as a matter of law without prejudice and stated that it would not hear the case based on 'voluntary jurisdiction.' The court concluded that it could not hear the case because there was no code or statute directly regulating the issue at hand to allow the court to decide whether a party could make the determination to interrupt medically supplied nutrition and hydration on behalf of an incompetent person. ${ }^{132}$ This procedural posture stands in stark contrast to Schiavo, where the law was clear and the case simply turned on applying the facts of the case to well-established principles of end-of-life decisionmaking law.

In February 2002, Mr. Englaro filed a new petition with the Trial Court, again requesting permission to discontinue medically supplied nutrition and hydration. Again, the Trial Court rejected Mr. Englaro's request, based on the same

130. Id. (referring to Trib. Lecco, Persons, Minors and Family Sect., 1 Mar. 1999, n. 59/99, 2 (Englaro I)).

131. Id. at 2-3 (referring to Corte App. Milano, Persons, Minors and Family Sec., 31 Dec. 1999, n. 99/99, 2 [hereinafter Englaro II]).

132. Id. (referring to Englaro II, supra note 131, at 5-17). 
reasoning as the previous decision. ${ }^{133} \mathrm{Mr}$. Englaro asked the Court of Appeal to review the Trial Court's decree, and in October of 2003, the Court of Appeal dismissed the case for the same reason. ${ }^{134}$ This time, with the help of a new lawyer who was a professor of Constitutional law, Mr. Englaro filed an extraordinary recourse to Corte di Cassazione (Cassazione) under Article 111 of the Constitution to review whether the Court of Appeal had correctly interpreted and applied the law. ${ }^{135}$

The Cassazione issued its decision in April of 2005 dismissing the case, but for a different reason than the Court of Appeal. ${ }^{136}$ The court determined that it could not decide such an important and deeply personal issue as refusal of life-sustaining treatment without a judicially appointed special guardian (a guardian ad litem) participating in the proceeding to ensure that the decision to refuse life-sustaining treatment would have been what the incompetent patient would have decided if competent. Because decisions about life-sustaining treatments are deeply personal, the court ruled that a general guardian cannot be authorized to act on the behalf of his or her ward, but must act "with" the incompetent patient, so to speak, to try to actualize his or her will. Furthermore, since the general guardian might have a conflict of interest, and because the decision is extremely important, the court ruled that it was necessary to appoint another, special, guardian (a guardian ad litem) in order to establish that the previously appointed general guardian was accurately reconstructing the will of the patient. A later decision

133. Id. at 3 (referring to Trib. Lecco, Sect. II, 15 Jul. 2002, n. 868/2002, 3-7 [hereinafter Englaro III]).

134. Id. (referring to Corte App. Milano, Persons, Minors and Family Sect., 17 Oct. 2003, n. 321/02, 1-17 [hereinafter Englaro IV]).

135. The Corte di Cassazione (the Supreme Court of Cassation) is the "highest court in civil and criminal matters, and reviews only errors of law... The function of the Supreme Court is not only that of reviewing appellate or non-appealable judgments, [but the court also] assures the exact observance and the uniform interpretation of the law, [and] the unity of national law." Vincenzo Varano, Machinery of Justice, in INTRODUCTION TO ITALIAN LAW 99, 108 (Jeffrey S. Lena \& Ugo Mattei eds., 2002).

136. Englaro IX, supra note 128, at 3 (referring to Cass., sect. I civil, 20 Apr. 2005, n. 8291, 1 [hereinafter Englaro V]). 
of this same court demonstrated that the true issue was not whether the guardian could act as a proxy decisionmaker on behalf of the incompetent patient, but rather whether the wishes of the incompetent patient could be ascertained and whether acting in conformance with those wishes would be lawful.

In response to the Cassazione's decision, Mr. Englaro filed a petition requesting appointment of a guardian ad litem in September of 2005. The court appointed an attorney, Franca Alessio, as guardian ad litem, and she agreed with Mr. Englaro that Ms. Englaro's medically supplied nutrition and hydration should be discontinued. Once again, however, the Trial Court rejected Mr. Englaro's request to discontinue life sustaining treatment, holding that the guardian could not decide to withdraw medically supplied life-sustaining treatment in place of, or for, the incompetent patient, even with the consent of the guardian ad litem.137 Here, the court reasoned that the incompetent patient lacked a constitutional right of autonomy and a constitutional right to consent to a medical treatment. In addition, in the opinion of the court, medically supplied hydration and nutrition was not a medical treatment but was ordinary care that could not be withheld or withdrawn unless death was imminent. As a patient in a PVS, Ms. Englaro's death was not imminent; patients in PVSs can live for decades. ${ }^{138}$

Near the end of 2006, the Court of Appeal reversed the Trial Court's decision, declaring that Articles 357 and 424 of the Civil Code vest the legal representative of a person who has been declared incompetent with the power to care for the incompetent person. Nevertheless, the court dismissed Mr. Englaro's petition to withdraw life-sustaining treatment, holding that the evidence was insufficient to clearly indicate that Ms. Englaro would have wanted to terminate her medically supplied nutrition and hydration. ${ }^{139}$ Mr. Englaro appealed the Court of

137. Id. (referring to Trib. Lecco, sect. I civil, 20 Dec. 2005, n. 1094/05, 6-21 [hereinafter Englaro VI]).

138. See Bryan JenNETt, The Vegetative STATE: Medical Facts, ETHICAL AND LEGAL DILEMMAS 66 (2002).

139. Englaro IX, supra note 128, at 10 (referring to Corte App. Milano, sect. I 
Appeal's decision to the Cassazione.

\section{THE CASSAZIONE SPEAKS (ENGLARO VIII) ${ }^{140}$}

On October 16, 2007, the Cassazione issued a decision that would transform end-of-life decisionmaking law in Italy. ${ }^{141}$ In that decision, the court held that judges can authorize removal of medically supplied life-sustaining treatment for patients who have been declared incompetent when two conditions are met: (1) it is clear that the patient is in a permanent vegetative state (PVS), judged by scientific standards recognized at the international level, and (2) it can be determined by clear and convincing evidence that the patient would not wish to be kept alive through artificial means, based on the patient's personality, lifestyle, and conviction, through the representative of the patient. ${ }^{142}$

civil, 16 Dec. 2006, [hereinafter Englaro VII]).

140. See generally Cass., sect. I civil, 16 Oct. 2007, n. 21748 [hereinafter Englaro VIII], available at http://www.nsulaw.nova.edu/library_tech/library/resources /local/milan/index.cfm.

141. See id. at 1. Shortly before this Englaro decision, Italian courts had been inhospitable, to say the least, to pleas for authorization of withdrawal of lifesustaining treatment. See, e.g., Trib. Rome, ordinance 16 Dec. 2006, Piergiorgio Welby c. Antea Associazione Onlus (refusing to order a physician to follow the wishes of a patient who wished to be disconnected from a ventilator). For a comparison between Englaro and Welby, see C. Tripodina, Il risvolto negativo del diritto alla salute: il diritto di rifiutare le cure. Studio in prospettiva comparata di due recenti casi italiani: il caso Welby $e$ il caso Englaro, in SISTEMI COSTITUZIONALI, DIRITTO ALLA SALUTE E ORGANIZZAZIONE SANITARIA (R. Balduzzi ed., 2009).

142. Englaro VIII, supra note 140, at 19-20. The Cassazione rejected Mr. Englaro's argument that the request to discontinue life sustaining treatment could be grounded in the concept of "accanimento terapeutico." Loosely translated, "accanimento terapeutico" is analogous to the legal/ethical/moral concept of futile medical treatment. THE RIGHT TO DIE, supra note 10 , at $\S 13$. The Italian deontological code (i.e., the statue that governs the practice of medicine in Italy) allows physicians to lawfully interrupt, or in some cases, refrain from administering treatment to patients if the physicians determine that the procedure would be accanimento terpeutico. To illustrate, if an imminently terminal cancer patient suffers from a cardiac arrest, administering cardiopulmonary resuscitation would be an "accanimento terapeutico." Whether a particular treatment is accanimento terapeutico must be determined by an objective standard and must be decided by the physician or the law. Since a patient in a PVS is not "terminal," providing life sustaining treatment for the patient cannot objectively be considered accanimento terapeutico. Furthermore, a subjective determination of a patient's "quality of life" cannot be a consideration in determination of accanimento terapeutico. 
The Cassazione remanded the case to the Court of Appeal to determine whether the evidence presented would clearly indicate that Ms. Englaro would wish to discontinue medically supplied hydration and nutrition. On remand, the Court of Appeal, after consideration of all the facts and evidence presented in the case, granted Mr. Englaro's request to discontinue Ms. Englaro's medically supplied hydration and nutrition. ${ }^{143}$

\section{The Political RESPONSE}

Similar to Schiavo in America, Englaro VIII and IX created a political furor in Italy, ${ }^{144}$ prompting the Italian Parliament to act much as the Florida and federal legislatures were prompted to act regarding Ms. Schiavo's treatment. The Chamber of Deputies and the Senate of the Republic filed an appeal to the Corte costituzionale della Repubblica Italiana (Constitutional Court) ${ }^{145}$ alleging that the Cassazione's October 16, 2007, decision and the Court of Appeal's decision in July 2008 violated the Italian Constitution. They asserted that the courts had violated the separation of powers provision in the Constitution by creating new laws in the area of end-of-life decisionmaking. The legislature claimed that since the courts' decisions were not based on interpretation of any laws in force at the time, the courts had overstepped the boundary between creating law, which is exclusively in the realm of the Parliament, and

143. Englaro IX, supra note 128 , at 28.

144. See Richard Owen, Death of Coma Woman a Crime: Vatican, THE AUSTRALIAN, Feb. 11, 2009, at 32; Rachel Donadio, Death Ends Coma Case that Set Off Furor in Italy, N.Y. TIMES, Feb. 10, 2009, at A7; Day \& McVeigh, supra note 3, at 8 (describing Englaro as exposing "faultlines that run through Italian society, with politicians, campaigners and the church battling for the country's soul"); Peter Popham, Church Fury as Coma Woman Allowed to Die: Italian Court Grants Father Right to End Daughter's Life, THE INDEPENDENT (LONDON), Nov. 14, 2008, at 32.

145. In Italy, the Constitutional Court conducts judicial review of legislation. This body, separate from the Cassazione and composed of fifteen judges, is vested with the power to review whether a national law, regional law, or government acts having the force of law violates the Italian Constitution. See Mario Comba, Constitutional Law, in INTRODUCTION TO ITALIAN LAW 31, 53-55 (Jeffrey S. Lena \& Ugo Mattei eds., 2002). 
interpreting law, which is the proper role of the court. ${ }^{146}$

The Constitutional Court disagreed with the Parliament. It concluded that the substance of the Parliament's argument amounted to an attack on the judicial reasoning of the case, in that the members of Parliament advanced numerous criticisms regarding the courts' selection, use, and interpretation of important legal materials within their decisions. ${ }^{147}$ The court ruled that the selection, use, and interpretation of legal materials are all within the realm of the judiciary, and courts engaging in those activities are not encroaching upon the powers of the Parliament. ${ }^{148}$ Furthermore, the court stated that the Parliament could still adopt a specific law regarding end-of-life decisionmaking within the constitutional framework. ${ }^{149}$ Therefore, the Constitutional Court declared the Parliament's petition inadmissible.

In addition to the Parliamentary response, the decision also prompted other official actions. The General Public Prosecutor of Milan protested against the judgment of the Court of Appeal of Milan (Englaro IX), but the Cassazione ruled that he lacked standing to challenge Englaro IX. ${ }^{150}$ Additionally, in response to the decisions, the Italian Health Minister sent inspectors to visit the clinic where Ms. Englaro lay. ${ }^{151}$ The Minister also declared

146. The interaction and relationship between creating law and interpreting law is complex in a Civil Law legal system. See JOHN HENRY MERRYMAN \& ROGELIO Perez-Perdomo, THE Civil LaW Tradition: AN Introduction to the legal SYSTEMS OF EUROPE AND LATIN AMERICA 20-26, 34-47 (2007).

147. Corte Cost., 8 Oct. 2008, n. 334, 7, available at http://www.nsulaw.nova.edu/ library_tech/library/resources/local/milan/index.cfm. For a comment, see $\mathrm{R}$. Romboli, Il conflitto fra poteri dello Stato sulla vicenda E.: un caso di evidente inammissibilità, in FORO ITALIANO 49 (2009); R. Bin, Se non sale in cielo, non sarà forse un raglio d'asino? (a proposito dell'ord. 334/2008), in FORUM DI QUADERNI COSTITUZIONALI, available at www.forumcostituzionale.it.

148. Corte Cost., 8 Oct. 2008, n. 334, 7, available at http://www.nsulaw.nova.edu/ library_tech/library/resources/local/milan/index.cfm.

149. Id.

150. Cass., united sections, 13 Nov. 2008, n. 27145 (Englaro X).

151. See Silvia Aloisi, Woman in Italian Right-to-Die Case Dies, ReUTERs UK, Feb. 9, 2009, available at http://uk.reuters.com/article/idUKTRE5185W220090209. See also Peter Popham, Italian Coma Woman's Death Ends Berlusconi's Bid to Keep Her Alive: Senators Thwarted in Bid to Fast-Track Law to Replace Force-Feeding Tubes, THE INDEPENDENT (LONDON), Feb. 10, 2009, at 20 (describing campaign to "threaten[] 
that medically supplied nutrition and hydration constituted ordinary care and not a medical treatment. In doing so, the Minister attempted to invoke the United Nations Convention for the protection of the rights of persons with disabilities in order to shift Englaro's legal question from the issue of the right to consent to or refuse medical interventions, to the issue of protection of persons with disabilities. ${ }^{152}$ The European Court of Human Rights (ECHR) issued a judgment of inadmissibility against the petition presented by groups of Italian citizens and associations that argued Englaro IX violated the European Convention of Human Rights. ${ }^{153}$

Englaro VIII and Englaro IX also prompted the General Health Director of the Lombardy Region, vested with the region's executive power, to instruct organizations within the

clinics which agreed to supervise the final stages of Eluana's treatment and the replacement of food with sedatives"); Day \& McVeigh, supra note 3 , at 8 (describing the actions of Italy's Minister of Labour, Health \& Social Policies (Welfare) in "threaten[ing] any clinic that helped Eluana to die with financial ruin, or in his words 'unimaginable consequences'"). The clinic in which Ms. Englaro eventually died was a private institution that did not receive public funding. See id.

152. Minister of Labor, Health \& Social Policies (Welfare), Address to the Presidents of Regions and Autonomous Provinces of Trento and Bolzano on Stati vegetativi, nutrizione e idratazione ("Vegetative states, nutrition and hydration") (Dec. 16, 2008). For a commentary, see Federico Gustavo Pizzetti, L'atto del Ministro Sacconi sugli stati vegetativi, nutrizione e idratazione, alla luce dei principî di diritto affermati dalla Cassazione nel caso Englaro, 84 ASTRID RASSEGNA (Jan. 12, 2009). This act of the Minister of Labor, Health \& Social Policies (Welfare), which is administrative rather than legislative, was directed and addressed to the Regions and Autonomous Provinces in an effort to ensure that public health facilities guarantee that medically supplied nutrition and hydration be provided, even when patient had expressed his or her desire not to receive it. An association of citizens called "Movimento Difesa del Cittadino" has protested before the Regional Administrative Tribunal for Latium, asking those administrative judges to nullify the Minister's act on the grounds that it violates articles 2 and 32 of the Italian Constitution, articles 1 and 3 of European Charter of Fundamental Rights, and article 1 of Act n. 180/1978. Another group of citizens, the "Movimento per la Vita," has intervened into the legal dispute "ad opponendum," and the administrative tribunal, has ruled that it lacks jurisdiction over the matter. See Administrative Tribunal for Latium Region, sez. III quarter, n. 8650/2009. Indeed, in Italy, when an individual's substantive right is at stake and the matter is not within the exclusive jurisdiction of the administrative justice, civil judges rather than administrative tribunals possess jurisdiction.

153. Press Release, European Court of Human Rights, Inadmissibility Decision, Ada Rossi and Others v. Italy (Dec. 22, 2008) (The court dismissed the case, reasoning that Englaro IX had not affected the parties). 
regional health service, including hospices such as the one in which Ms. Englaro was a patient, that they could not withdraw or withhold medically supplied nutrition and hydration from patients. Mr. Englaro argued against this "administrative act" before the administrative tribunal, and the administrative judges agreed with his argument. When there is a specific judgment from a civil court (and, in this case of the highest civil court, the Cassazione), recognizing an individual's fundamental, constitutional right, the executive branch must respect that right as if it had been granted by a statutory source of law. The executive could not prevent individuals from securing and exercising the right. ${ }^{154}$

Eluana Englaro died on February 9, 2009, after the PEG tube was removed. ${ }^{155}$

Englaro VIII and Englaro IX revolutionized Italian end-of-life decisionmaking law. Prior to these decisions, a patient in a PVS had no recourse or mechanism through which to direct the withdrawal or withholding of life sustaining treatment. The next section will explore the judicial reasoning of Englaro VIII, comparing and contrasting it with the reasoning of U.S. end-oflife decisionmaking law, including the judicial opinions in Schiavo.

\section{Similar Paths But SubSTantial DifFERENCES}

Although the Englaro litigation took a path very similar to Schiavo, there are many significant differences between the two cases. As opposed to Schiavo, which was a usual end-of-life decisionmaking case presenting issues involving well-settled Florida law, the end-of-life decisionmaking laws facing Mr. Englaro in his quest to withdraw Ms. Englaro's treatment were

154. The administrative tribunal also held that the right to refuse medically supplied nutrition and hydration is of a fundamental, constitutional nature and the right had to be respected even if a guardian was communicating the refusal. It additionally ruled that the right to refuse life-sustaining treatment does not constitute euthanasia, which it defined as the use of a "behavior intentionally aimed to shorten life and that causes itself positively the death."

155. See Owen, supra note 144 , at 32. 
far from settled. Ms. Englaro's litigation proceeded in an uncertain legal environment. ${ }^{156}$ Indeed, the Court of Appeals denied Mr. Englaro's first two petitions requesting discontinuation of life-sustaining treatment because it concluded that there were no laws or regulations that applied to the issues before the court. And, in fact, no specific piece of legislation authorizing withdrawal of treatment existed. In existence, however, were general legislative provisions that were potentially applicable and constitutional clauses that were on point. In this respect, Englaro VIII is much more like Quinlan; the Cassazione based its ruling on "higher-level," constitutional authority without specific statutory provisions in effect.

In the absence of any parliamentary act specifically authorizing end-of-life decisionmaking, the Cassazione arguably engaged in lawmaking based on its interpretation of the constitution, the ultimate source of law. As such, the Cassazione's decision was susceptible to an attack from the Parliament, arguing that the judiciary had engaged in an impermissible activity. ${ }^{157}$ Even in the civil law legal system, however, the role of the judiciary is to interpret the law and the

156. In some respects, "end-of-life decisionmaking law" did not exist in Italy before Englaro VII; that was precisely the reason the Court of Appeal in Englaro dismissed Mr. Englaro's claim. In other respects, however, "end-of-life decisionmaking law" did exist. The Constitutional Court ruled that the Cassazione did not create law (which would have violated the separation of powers doctrine) but instead applied law that already was in force. So it would be accurate to say that, prior to Englaro, "end-of-life decisionmaking" law existed in Italy at a constitutional level and at a supranational level (through the Oviedo Convention on Human Rights). Because Italy has (and had prior to Englaro) criminal laws punishing assisted suicide and homicide of even persons who ask to be killed, commentators who opposed the ruling of the Cassazione argued that "end-of-life decisionmaking" law existed and they forbid withholding or withdrawing lifesustaining treatment. This paradox highlights the controversial nature of end-oflife decisionmaking laws. It also emphasizes the similarity between Englaro VIII and Quinlan. The only specific piece of legislation governing the actions Mr. Englaro contemplated appeared in the Criminal Code, but general principles and constitutional provisions also applied. This was the same dilemma Mr. Quinlan took to the New Jersey Supreme Court.

157. The interaction between a judge interpreting law and the legislature creating law is complex in a civil-law legal system. See MERRYMAN \& PÉREZPERDOMO, supra note 146 , at $34-47$. 
Constitution is the ultimate source of law. ${ }^{158}$ Hence, the Constitutional Court held that the Cassazione had the power to interpret the Constitution in a manner as to provide incompetent patients the right to have life-sustaining treatment withdrawn or withheld based upon what they would have wanted if they had been competent to make their own decisions. ${ }^{159}$

\section{INFORMED CONSENT: COMMON LAW VERSUS CONSTITUTIONAL SOURCES}

Similar to the U.S. Supreme Court's decisions preceding Schiavo, ${ }^{160}$ the Cassazione in Englaro established the right of individuals to refuse life-sustaining treatment pursuant to the doctrine of informed consent. Unlike the U.S. Supreme Court, which has thus far refrained from expressly finding a constitutional source for the right, the Cassazione found the principle of informed consent in the Italian Constitution. The court declared that the principle of informed consent is derived from the following articles in the Italian Constitution: "in Article 2, which protects and promotes the fundamental rights of the human person, of her identity and dignity; in Article 13, which proclaims the inviolability of personal liberty... and in Article 32, which protects health as a fundamental right of the individual...."161 According to the Cassazione, consent is intricately linked to the concept of personal and physical liberty as expressed in Article 13 of the Italian Constitution, which protects individuals from being detained, inspected, or searched against their will. In fact, in addition to Article 32 of the Constitution, Act no. 833/1978, Article 33 declares that medical treatment is voluntary and treatment is compulsory only when

158. See Comba, supra note 145, at 31, 53-55; MERryMAn \& PÉREZ-PERdomo, supra note 146, at 34-47; see also A. VEDASCHI, Italian Sources of Law, in INTRODUCTION TO ITALIAN PUBLIC LAW, (F. Ferrari ed., Giuffrè 2008), especially chapter XI, 220-21.

159. Corte Cost., 8 Oct. 2008, n. 334, 7.

160. See Washington v. Glucksberg, 521 U.S. 702 (1997); see Vacco v. Quill, 521 U.S. 793 (1997); see Cruzan v. Dir., Mo. Dep't of Health, 497 U.S. 261 (1990).

161. Englaro VIII, supra note 140 , at 9. 
prescribed by law. ${ }^{162}$

The Italian doctrine of informed consent thus diverges from the doctrine of informed consent in the U.S. in that informed consent law in the U.S. has its origin and basis in the common law of tort. ${ }^{163}$ As stated previously, locating the right to make end-of-life decisions in the Constitution is significant in that the legislature cannot override constitutional rights, whereas it can always override legal decisions emanating from common-law sources. ${ }^{164}$ While the U.S. Supreme Court has defined that right as stemming from the tort law of battery (i.e., as arising from the right to be free from unwanted bodily touching), ${ }^{165}$ the Cassazione determined that Italy's constitution guarantees its citizens the right to make deeply personal choices about the medical treatments they want to receive or refuse, as part of their personal conception of human dignity, at least when life is artificially prolonged as the result of the medical treatment in question. ${ }^{166}$

In this respect, the Cassazione's opinion is much more theoretically expansive than the U.S. Supreme Court's vision of the right to refuse life-sustaining treatment has been thus far. The Cassazione's decision calls to mind a famous passage from the U.S. Supreme Court's decision in Planned Parenthood of Southeastern Pennsylvania $v$. Casey ${ }^{167}$ describing the liberty interest in autonomy protecting reproductive choices under the U.S. Constitution:

These matters, involving the most intimate and

162. The Cassazione cited two Constitutional Court decisions, 258/1994 and $118 / 1996$, permitting the government to provide treatment where non-treatment would cause harm to the health of others and the treatment provided does not cause harm and benefit the health of the patient. See id. at 11.

163. See Cerminara, Three Female Faces, supra note 17, at 97.

164. See id. at 99; see Baron, supra note 35, at 121 (2004).

165. Glucksberg, 521 U.S. at 724.

166. See Englaro VIII, supra note 140, at 10 (stating "Consent is tied to the moral liberty of the subject and to his self-determination, as well as to his physical liberty defined as the right to the respect of his own corporeal integrity, which are all aspects of the personal liberty proclaimed inviolable by Article 13 of the Constitution.").

167. See Planned Parenthood v. Casey, 505 U.S. 833 (1992). 
personal choices a person may make in a lifetime, choices central to personal dignity and autonomy, are central to the liberty protected by the Fourteenth Amendment. At the heart of liberty is the right to define one's own concept of existence, of meaning, of the universe, and of the mystery of human life. Beliefs about these matters could not define the attributes of personhood were they formed under compulsion of the State. ${ }^{168}$

Similarly, the Italian justices have recognized that both the right to life and the right to bodily integrity derive from a matrix of human dignity ${ }^{169}$ implicitly recognized by Articles 2, 13 and 32 of the Italian Constitution. ${ }^{170}$ The substance of the human

168. Id. at 851

169. For an introduction to the "constitutional," "value," and legal concept of human dignity in Italian law, see A. PIROzZOLI, Il VALORE COSTITUZIONALE DELla DIGNITÀ. UN'INTRODUZIONE (2007); LA TUTELA DELLA DIGNITÀ DELL'UOMO (E. Ceccherini eds., Editoriale Scientifica 2008); U. VINCENTI, DIRITTI E DIGNITÀ UMANA (Laterza 2009).

170. See Corte Cost., 9 July 1996, n. 238; see also Corte Cost., sent. 23 Dec. 2008, n. 438 (affirming that "informed consent" to a medical intervention shall be considered a constitutional principle representing the synthesis of two fundamental, specific constitutional rights of the person recognized and guaranteed by Art. 2, 13, and 32 of the Constitution: the right of autonomy and selfdetermination in medical choices arising from the right of personal liberty, and the right of health and physical and psychological welfare). Most recently, see Cass., criminal joint sections, 18 Dec. 2008, n. 2437 (affirming that the principle of informed consent is paramount and firmly grounded in the Constitution as a declination of the fundamental principles of human dignity, personal identity and autonomy, and that medical activity, in order to be lawful, generally must be grounded in informed consent from a competent patient). See also Cass., sect. IV criminal, 14 Mar. 2008, n. 11335; Cass., sect. III civil, 14 Mar. 2006, n. 5444.

About the Italian doctrine of informed consent for medical operations, see A. SANTOSUOSSO, CORPO E LIBERTÀ, (Raffaello Cortina 2001); G. MONTANARI VERGALlO, Il RAPPORTO MEDICO-PAZIENTE, (Giuffrè 2008); P. VERONESI, Il CORPO E LA COSTITUZIONE, (Giuffre 2007); S. TORDINI CAGLI, PRINCIPIO DI AUTODETERMINAZIONE E CONSENSO DELL'AVENTE DIRITTO, (Bononia University Press 2008); about art. 32 Cost. and its interpretations, see B. Caravita di Toritto, $L a$ Disciplina Costituzionale della Salute, DIRITTO E SOCIETÀ 52 (1984); A. D’Aloia, Diritto di Morire? La Problematica Dimensione Costituzionale della «fine della vita», POLITICA DEL DIRITTO 611 (1998); M. Luciani, Il Diritto Costituzionale alla Salute, DIRITTO E SOCIETA 780 (1980); M. Portigliatti Barbos, Diritto di Rifiutare le Cure (voce), 4 Digesto. Discipline PENAListiche 32 (Utet 1990); I. Nicotra Guerrera, "Vita" E SISTEMA DI VALORI NELLA COSTITUZIONE, (Giuffrè 1997); G.U. Rescigno, Dal Diritto di Rifiutare un Determinato Trattamento Sanitario, Secondo l'art. 32, co. 2 Cost., Al Principio di Autodeterminazione Intorno alla Propria Vita, DIRITTO PUBBLICO 85 (2008); A. Simoncini \& E. Longo, Articolo 32, 1 CommEntario alla COSTITUZIONE ITALIANA, 655 (R. Bifulco et al., eds., Utet 2006). 
dignity the Italian Constitution guarantees as a fundamental principle and value (the "source" of every other right protected by the Constitution) belongs to each individual, to determine on his or her own terms. Therefore, it must be combined with the constitutional principle and value of personal identity, ${ }^{171}$ from which springs the right of every person to develop his or her own personality, protected by Article 2 of the Constitution. ${ }^{172}$ The result is that every person has a liberty right to accept or refuse a medical treatment that is not imposed by the law for public health reasons and that the interest in preservation of life ${ }^{173}$ does not always limit that liberty..$^{174}$

This decision reaches much farther than does American constitutional jurisprudence. After the U.S. Supreme Court assumed the existence of a constitutional right to refuse lifesustaining treatment in Cruzan, ${ }^{175}$ the Court later denied in Glucksberg that the right it had recognized was "deduced from abstract concepts of personal autonomy."176 When asked whether a state law prohibiting assistance to terminally ill patients in ending their lives was unconstitutional, Justice

171. About the legal protection of the several dimensions of "personal identity" at the constitutional level with respect to new developments in biotechnology, see Paolo Zatti, Dimensioni ed Aspetti dell'Identità nel Diritto Privato Attuale, 4 LA NUOVA GIURISPRUDENZA CIVILE COMMENTATA, 4-5 (2007).

172. About various aspects of the development of each personality in a world characterized by technological development and the area covered by new constitutional human rights (especially for thoughts about the end of life decisionmaking in Italy and abroad), see STEFANO RODOTÀ, LA VITA E LE REGOLE. TRA DIRITTO E NON DIRITTO, (Feltrinelli 2006).

173. Giorgio Lombardi, Intervista sul Caso Terry Schiavo, 3 QUADERNI COSTITUZIONALI, 695, 695-700 (2005), distinguishes between a "natural life" and an "artificial, sustained" one, observing that a person in a vegetative state is no longer able to autonomously develop. He argues that a clinical decision adopted by a patient exercising his or her liberty right to consent to or refuse therapy, may choose or refuse to endure the latter ("artificial sustained") existence.

174. See Nicola OCChIOCupo, Liberazione e Promozione della Persona UMANA: UNITÀ DI VALORI NELLA PLURALITÀ DI POSIZIONI, (Giuffrè 1988); V. Baldini, Sviluppi della Medicina e Dialettica dei Diritti Costituzionali, 1 STUDI IN ONORE DI GIANNI FERRARA 240 (Giappichelli 2005).

175. Washington v. Glucksberg, 521 U.S. 702, 723 (1997) (noting that the Court in Cruzan assumed but did not hold that the right existed).

176. Id. at 725 (declining to hold that a constitutional right to having assistance in ending one's life existed). 
Rehnquist, writing for the Court, ruled that the right at issue in Cruzan had been grounded in the tort right to be free from nonconsensual touching. Specifically addressing the argument that the right to refuse life-sustaining treatment emanated from the broadly defined liberty interest described in Casey, the Court concluded that simply because "many of the rights and liberties protected by the Due Process Clause sound in personal autonomy does not warrant the sweeping conclusion that any and all important, intimate, and personal decisions are so protected ...."177

Substantial differences at the heart of the two countries' legal systems underlie the distinction. For example, differences between the U.S Constitution and the Italian Constitution may have caused this divergent path. The Cassazione in Englaro ruled that it was the combination of express Italian constitutional provisions protecting human identity, dignity, and liberty that underlay the right to refuse treatment in Ms. Englaro's case. Indeed, the Italian Constitution provides more enumerated rights than does the U.S. Constitution. ${ }^{178}$ Even generally speaking, with fewer enumerated rights with which to work, courts recognize a more limited category of fundamental rights in the U.S. ${ }^{179}$ In particular, the Court in Cruzan (and, later, interpreting (ruzan) worked not with specifically enumerated rights, but rather with a general Due Process Clause. In interpreting Cruzan in Glucksberg, the U.S. Supreme Court sent

177. Id. at 727 (citing San Antonio Independent School Dist. v. Rodriguez, 411 U.S. 1, 33-35 (1973)).

178. There are 42 articles in the Italian Constitution, many of which enumerate the rights and duties of Italian citizens. The U.S. Constitution does not impose any duties upon its citizens, yet, even focusing solely on rights, the contrast between the two constitutions is striking. The following are some of the rights the Italian Constitution recognizes that are not recognized as fundamental rights in the U.S.: the right to health (Article 32), the right to education (Article 34), the right to welfare (Article 38) and the right to strike (Article 40).

179. While the Bill of Rights enumerates some fundamental rights, the U.S. Supreme Court has recognized others that the Constitution does not explicitly set forth. For further discussion on this issue, see Chapter 5 (The Structure of the Constitution's Protection of Civil Rights and Civil Liberties) and Chapter 8 (Fundamental Rights Under Due Process and Equal Protection) in ERWIN CHEMERINSKY, CONSTITUTIONAL LAW 523, 524, 943-44, 1040-41 (3d ed. 2009). 
an unmistakable signal that it will not interpret the U.S. Constitution's general liberty interest to encompass concerns about human identity and dignity with respect to all matters. In contrast, working with enumerated rights, the Cassazione recognized that medical decisionmaking is a matter of identity and dignity when those specified Italian constitutional rights combine with the constitutional right to health. ${ }^{180}$

Similarly, differences in the type of legal system in effect in Italy and the U.S. also contributed to the Cassazione's locating the right to refuse life-sustaining treatment in the Italian Constitution. It would be impossible to establish a continually developing law of informed consent using tort-law principles in this sort of case in Italy for two reasons. First, while tort law does exist in Italy, it arises out of provisions of the Civil Code relating to compensation for harm done to others, not relating to medical decisionmaking for incompetent patients by their guardians. ${ }^{181}$ Second, while the Cassazione's interpretation of the statutory scheme and the Italian Constitution would be persuasive to other Italian courts, in a civil-law system such as

180. The Cassazione will not, however, follow the concepts of human identity, dignity and liberty as far as proponents of the Casey formulation of the U.S. Constitutional right had urged the U.S. Supreme Court to follow them. When the Court in Glucksberg refused to follow Casey with respect to end-of-life decisionmaking, it did so in response to arguments that human dignity, liberty and autonomy required a declaration that a state statute prohibiting assistance to terminally ill patients in dying was unconstitutional. The Court refused to declare that statute unconstitutional, and the Cassazione has similarly stated that it would not find a right to assistance in dying in the Italian Constitution. See Glucksberg, 521 U.S. 702; Vacco v. Quill, 521 U.S. 793 (1997); Englaro VIII, supra note 140.

An American court working with multiple enumerated rights at the state constitutional level has ruled that the combination of state constitutional rights to human dignity and privacy results in "a competent terminally ill patient ha[ving] the constitutional right to die with dignity" which invalidates state statutes that prevent such a patient from receiving assistance in dying. See Baxter v. State, 2008 Mont. Dist. LEXIS 482, at *29 (D. Ct. Mont. 2008).

181. Article 2043 of the Civil Code states: "Any fraudulent, malicious, or negligent act that causes an unjustified injury to another obliges the person who has committed to act to pay damages." THE ITALIAN CIVIL CODE 140 (Susanna Beltramo ed., 2010) [hereinafter CIVIL CODE]. Combined with Article 32 of the Italian Constitution, assuring citizens a right to health, physicians may be held liable for operating on patients without their consent. The Englaro case did not arise in the context of a lawsuit against a physician, which would appear to render these Italian tort law principles inapplicable in many end-of-life decisionmaking situations. 
Italy's, the doctrine of stare decisis ${ }^{182}$ does not exist; judicial opinions are not formally and legally binding upon later courts on the same or lower levels. ${ }^{183}$

The Cassazione thus interpreted the Italian statutes and constitution to encompass the doctrine of informed consent, which Americans tend to think of as a tort concept, and to encompass it quite broadly. First, it stated that informed consent provides the right to consent to treatment as well as the right to refuse treatment. ${ }^{184}$ The court supported this interpretation of informed consent by citing national ${ }^{185}$ and supranational ${ }^{186}$

182. Stare decisis is a common-law doctrine pursuant to which courts must follow previous judicial decisions on the same issue. BLACK'S LAW DICTIONARY 1537 (Bryan A. Garner et al. eds., 9th ed. 2009). Cf. jurisprudence constante (a civil law doctrine pursuant to which a "court should give great weight to a rule of law that is accepted and applied in a long line of cases, and should not overrule or modify its own decisions unless clear error is shown and injustice will arise from continuation of a particular rule of law."). Id. at 933.

183. Article 101 of the Italian Constitution states that the judges are "subject[ed]" (i.e., must apply) "only to the "law," intended to include only statutory law. Although prior decisions of the Italian civil, administrative, and criminal courts cannot be considered as sources of law, they are persuasive instruments for the interpretation of the Constitution, the statutes, the European Community regulations and directives. Frequently lower and higher courts cite prior decisions in order to sustain their arguments and legal rationale. Embedded in the civil procedure law and judiciary act, the Cassazione has the duty to assure the uniform interpretation of the statutes and the "unity" (the coherence) of the "national" legal framework. When a Court of Appeal has decided a case by applying the law as interpreted by the precedents of the Cassazione, the same Cassazione may simply refuse to hear the "recourse" against the decision of the Court of Appeal thereby letting the previous "case-law" or "interpretation" stand. Thus, there is a curious "mix," in which judges are encouraged to cite prior decisions of the Cassazione. However, since the Cassazione is composed of many judges divided into many sections, the precedents and interpretations of the Cassazione may not all be coherent. Thus, where a conflict of interpretation arises between one section of the Cassazione and another, the question may be referred to the "united sections," similar to the American en banc court, for resolution. See also MERRYMAN \& PÉREZ-PERDOMO, supra note 146.

184. For similar reasoning on the American side of the Atlantic Ocean, see, e.g., Werth v. Taylor, 475 N.W.2d 426, 428 (Mich. Ct. App. 1991) (“Indeed, the whole concept of informed consent to treatment leads to an inference of its converse informed refusal of treatment.").

185. The court cited an Italian legislative decree (n. 211/2003) which implemented a European directive (D.L. 4 Aprile 2001, n. 2001/20/EC, available at http://www.eortc.be/Services/Doc/clinical-EU-directive-04-April-01.pdf).

That decree discusses the requirements of good clinical practice in conducting clinical trials on medical products for human use and contains a provision specifically addressing consent given by a substitute decisionmaker for an 
incompetent patient. In addition, the court cited Italian statutes such as the law creating the National Health Service and the code of medical ethics, adopted by the national association representing Italian surgeons, which is an example of private, internal self-regulation that the Italian State recognizes. See Englaro VIII, supra note 140 , at 14. Additionally, the court also referred to several of its prior decisions for the basis of informed consent, though its prior decisions cannot be considered a source of law. See id at 9 .

186. The court cited the Charter of Fundamental Rights of the European Union and The European Convention on Human Rights and Biomedicine of 1997 ("Oviedo Convention"). See Englaro VIII, supra note 140, at 9. The Convention of Oviedo was drafted in the legal framework of the Council of Europe, an international organization that is different from the European Union. That Convention is an international treaty, which must be ratified by the President of the Republic, and the ratification of which the Italian Parliament must authorize with an ad hoc statute. See Act 28 Mar. 2001, n. 145 (also delegating legislative power to the Executive in order to adapt the Italian legal system to the principles and the norms of the Convention (art. 3); that legislative delegation, first extended in time by art. 49 , Act 16 Jan. 2006, n. 3 and subsequently reiterated by art. 3 of Act 27 Feb. 2007, n. 17, has never been exercised). Because the President of the Republic has never ratified the Convention, it was not a "source of law" for the Englaro court, although both the Cassazione in this case and the Constitutional Court in another matter have used it as an interpretive resource (as evidence of the constitutional heritage and tradition of the European states). See Englaro VIII, supra note 140, at 1415; Corte Cost. sent. 28 Jan. 2005, n. 46, n. 47, n. 48, n. 49, in which the court used the Convention to ascertain the constitutional admissibility of a request of referendum on the act regulating in vitro fertilization in Italy. For a comment about the process of ratification and implementation of the Convention in Italy, see Federico Gustavo Pizzetti, La Delega per l'Adattamento Dell'ordinamento Italiano alla Convenzione di Oviedo tra Problemi di Fonti ed Equilibri Istituzionali: un Nuovo "Cubo di Rubik"?, 3 RASSEGNA PARLAMENTARE 585-608 (2007).

The Convention of Oviedo thus differs in origin from the Charter of Fundamental Rights of the European Union, which is within the legal framework of the European Union. Since the Charter was never incorporated in the previous Treaties, of the European Union, it had no "legal force," formally speaking, even if it provided interpretative assistance, at the time Englaro VIII was decided. The Charter was, however, eventually incorporated into the Treaty of Lisbon, and Italy has ratified that treaty. When all member states of the European Union ratify the treaty, the Charter will possess the same legal force as any other treaty Italy has recognized and will become the primary source of the European Union's law, on the same level as the treaties. For further information regarding the complex interaction between European Union human rights protection and the European Union member states' constitutional law, see Paola Bilancia, Aspetti e Problemi Della Tutela Multilivello dei Diritti, in DignIDAD DE LA PERSONA, DERECHOS FundaMENTALES, JUSTICIA CONSTITUCIONAL Y OtROS ESTUDIOS DE DERECHO PUBLICO, 435 (Francisco F. Segado ed., 2008); see generally DAVID J. HARRIS ET AL., LAW OF THE EUROPEAN CONVENTION ON HUMAN RIGHTS (2d ed. 2009); see generally MARGOT HORSPOOL \& MATTHEW HUMPHREYS, EUROPEAN UNION LAW ( $5^{\text {th }}$ ed. 2008); see generally PRINCIPLES OF EUROPEAN CONSTITUTIONAL LAW (Armin von Bogdandy \& Jürgen Bast eds., 2006); see generally KOEN LENAERTS \& PIET VAN NUFFEL, CONSTITUTIONAL LAW OF THE EUROPEAN UNION (Robert Bray ed., 2d ed. 2005); ANDREW Z. DRZEMCZEWSKI, EUROPEAN HUMAN RIGHTS CONVENTION IN DOMESTIC LAW: A COMPARATIVE STUDY (2004); see generally KAREN J. ALTER, ESTABLISHING THE SUPREMACY OF EUROPEAN 
sources of law, as well as citing and distinguishing authoritative sources from other jurisdictions ${ }^{187}$ in arriving at its interpretation. Similar to the U.S. Supreme Court, the Cassazione determined that while informed consent provided the basis to refuse treatment, it would not provide the right to assisted death. ${ }^{188}$ Likewise, the Cassazione distinguished between refusing treatment, which allows an illness to follow its natural progression, and assisted death, which the court viewed as an action that hastens death. The Cassazione cited the U.S. Supreme Court decision in Vacco v. Quill ${ }^{189}$ to support its assertion that the right to refuse medical treatment is based on the right to bodily integrity, i.e., the right to refuse unwanted invasive interventions, and not from a general right to die. ${ }^{190}$

Despite echoing the U.S. Supreme Court's limitations on end-of-life decisionmaking rights, the Cassazione went farther in intellectual basis than the U.S. Supreme Court has gone in

LAW (2001).

187. The Cassazione cited Art. 1111-10 of the French Code of Public Health, inserted in Law No. 2005-370 of 22 April 2005, to substantiate its assertion that informed consent applies to situations in which refusal of care would result in the death of patients. On the other hand, the Cassazione distinguished the ECHR's case of Pretty v. United Kingdom, stating that although Pretty had determined that Article 2 of the Convention of the Protection of the Human Rights and of Fundamental Freedom does not provide the right to assisted death, the case does not stand for denying patients the right to refuse care even when that refusal would result in the patient's death.

Not surprisingly, the Cassazione's use of so many foreign authorities in its decision sparked discussion in Italy similar to the discussion that took place in America after the U.S. Supreme Court cited international authority in striking down a law prohibiting sodomy in Lawrence v. Texas. Compare Francesco Gazzoni, La Cassazione Riscrive la Norma Sull'Eutanasia, JUDICIUM, http://judicium.it/news/ins_26_11_07/

Gazzoni nuovi saggi.html (last visited May 9, 2011) (asserting that the Cassazione was forced to cite so many foreign decisions because of the lack of Italian law supporting its decision) with Lawrence v. Texas, 539 U.S. 558, 598 (2003) (Scalia, J., dissenting) (criticizing "[ $t$ ]he Court's discussion of foreign views" as "meaningless dicta. Dangerous dicta, however, since this Court should not impose foreign moods, fads, or fashions on Americans.").

188. Compare Englaro VIII, supra note 140, at 11-12 with Washington v. Glucksberg, 521 U.S. 702, 723 (1997); Vacco v. Quill, 521 U.S. 793, 799 (1997) (refusing to find a constitutional right for a terminally ill patient to receive assistance in ending his or her life through the prescription of prescription medications).

189. See generally id.

190. Englaro VIII, supra note 140, at 12. 
establishing a right to refuse life-sustaining treatment. Its constitutional right of autonomy, based upon enumerated rights to personal identity, dignity and liberty, provides a much firmer foundation upon which to build end-of-life decisionmaking law than does the common-law right of informed consent that the U.S. Supreme Court has identified, even with the constitutional basis that the Cruzan Court assumed for the American right.

\section{STANDARDS FOR PROXY DECISIONMAKING: SUBSTANTIVE AND EVIDENTIARY}

Having established a constitutionally grounded form of informed consent as the basis for the right to refuse lifesustaining treatment, the court then examined whether the right to refuse medical treatment applied to incompetent patients. ${ }^{191}$ That incapacitated patients themselves can exercise the right to refuse treatment through use of the doctrine of informed consent is a legal fiction because incapacitated patients do not have the capacity to make informed decisions contemporaneously; a proxy decisionmaker must be involved. ${ }^{192}$ It was thus necessary to give the incompetent patient the right, although the court recognized that an incompetent patient cannot act on his or her own behalf. Therefore, it granted the right to incompetent patients but placed two restrictions on the guardian with proxy decisionmaking authority on behalf of the incompetent patient. First, the guardian is not actually making his or her own

191. In this way, too, the Italian court mimicked the approach of many American courts. As long ago as Quinlan, for example, American courts considering these issues have proceeded in this order of inquiry. See In re Quinlan, 355 A.2d 647, 664 (1976) (the court's "affirmation of Karen's independent right of choice . . . would ordinarily be based upon her competency to assert it ... [n] evertheless [the court] concluded that Karen's right of privacy may be asserted on her behalf by her guardian under the peculiar circumstances here present."). See also Cruzan v. Dir., Mo. Dep't of Health, 497 U.S. 261, 279-80 (1990)(proceeding in same order).

192. Cruzan, 497 U.S. at 280 (stating that "[s]uch a 'right' must be exercised for her, if at all, by some sort of surrogate."); Cruzan v. Harmon, 760 S.W.2d 408, 417 (1988) (asserting that it would be "definitionally impossible for a person to make an informed decision - either to consent or to refuse - under hypothetical circumstances" because the three factors required for informed consent are not present when a patient is incapacitated). 
decisions; because the decision is deeply personal, the guardian is considered to be acting (fictitiously) "with" the patient in making the decision. Second, the guardian must not make the medical decision for the patient but must make the decision that the patient would have wanted made. That is, the Cassazione required the guardian to ascertain what the wishes of the patient would have been with regard to the treatment choice at hand, by examining evidence from the patient's life prior to the loss of decisionmaking capacity. ${ }^{193}$ In addition to any wishes the patient had expressed, a guardian may take into account the personality, lifestyle, and inclination of the patient, as well as the basic values of the patient, which consist of the patient's ethical, religious, cultural, and philosophical convictions.

Although the court explicitly used the term "best interest" in its opinion, it clearly did not mean to suggest usage of an American, purely objective, best interests standard for decisionmaking. Rather, it established the right to refuse medical treatment as part of the right of personal autonomy under the Italian Constitution (Article 13), which necessarily implies that the patient's wishes govern. The primary objective of the best interest standard is to make the decision that is in the best interest of the patient, rather than a decision based on the patient's wishes. A patient exercising his or her right to personal autonomy, however, is entitled to a decision that is the same as he or she would have made, without regard to whether others agree that it is in his or her best interest. Thus, identifying the right to refuse life-sustaining treatment as a matter of autonomy seems to preclude use of the best interest standard unless there is no evidence upon which to base a decision of what the patient would have wanted when competent to make decisions for him or herself. ${ }^{194}$ At this juncture, just as earlier, the court supported

193. See Quinlan, 355 A.2d at 664 ("The only practical way to prevent destruction of the right is to permit the guardian and family of Karen to render their best judgment, subject to the qualifications hereinafter stated, as to whether she would exercise it in these circumstances.").

194. An example of that sort of case might be one involving a patient who has been incompetent to make medical decisions all through his or her life. See, e.g., 
its interpretive reasoning with a multitude of cases decided in foreign jurisdictions, ${ }^{195}$ including three U.S. cases: Quinlan, In re Jobes $^{196}$ and Cruzan. Indeed, the Cassazione explicitly adopted the substituted judgment standard as enunciated in Quinlan, Jobes, and Cruzan.

On the issue of which evidentiary standard applies, the Cassazione, like most other jurisdictions, adopted the clear and convincing evidentiary standard of proof, although the language used by the court (that the proof must be "clear, univocal 197 and convincing"), could be interpreted to mean a standard of proof that is higher than clear and convincing. Clear and convincing evidence, as traditionally understood in America, does not require uncontroverted evidence. ${ }^{198}$ Yet the court's use of the term "univocal" could be read to indicate that the proof must be uncontroverted to be considered clear and convincing. Indeed, given the court's reminders that the guardian must act "with" the patient rather than "for" the patient, it seems as if the court would look unfavorably upon decisions made after making credibility determinations to choose between conflicting views of what the patient would have wanted.

Applying this standard to the facts of Englaro does not clarify this uncertainty. In Englaro, both of the parties (Mr. Englaro and the appointed guardian ad litem) agreed that Ms. Englaro would have wanted to discontinue life sustaining treatment. All of the evidence presented indicated that Ms. Englaro would have wanted to discontinue life sustaining treatment. In contrast, under the Schiavo facts, the Englaro court

THE RIGHT TO DIE, supra note 10 , at $\$ 4.04$.

195. Other cases the court cited included Bundesgerichtschof (in Germany's highest court of appeals), 17 Mar. 2003 judgment, and Bland, in the House of Lords, 4 Feb.1993.

196. In re Jobes, 529 A.2d 434, 444 (1987).

197. "Univocal" means "having one meaning only." A. MERRIAM-WEBSTER, WEBSTER'S NEW COLLEGIATE DICTIONARY 1280 (1974). In that sense, it is slightly different from "unequivocal," which means "clear, unambiguous," according to the same dictionary. Id. at 1277 . The difference may lie in whether the conclusion can exist in the presence of conflicting evidence, as explored in the text.

198. See THE RIGHT TO DIE, supra note 10, at § 3.27[A][1]. See, e.g., Schiavo I, supra note 105 , at 179 . 
might have decided the case differently. Schiavo involved disagreements about Ms. Schiavo's wishes, and the allegation of a financial conflict of interest was present in Schiavo but not present in Englaro. The court in Englaro spoke of the need for the proxy decisionmaker to act exclusively in the interest of the patient, so it is unclear how the court would have approached the case if there had been a conflict of interest present. In future cases, in which family members dispute what the patient would have wanted or one or more of the parties requesting discontinuance of treatment has a financial conflict of interest, it is uncertain how Englaro's evidentiary standard would be applied.

Going beyond the facts of Schiavo, moreover, the boundaries of the substantive standard the Cassazione announced become even more uncertain. It is unclear whether and to what extent the Cassazione's announced standard applies only to patients in PVS such as Ms. Englaro and Ms. Schiavo. Therefore, it is unclear what standard will apply to a patient incompetent due to another medical condition, due in part to the institutional roles of the courts in a civil law system. ${ }^{199}$

\section{MEDICALLY SUPPLIED NUTRITION AND HYDRATION}

The Cassazione was surprisingly clear on the issue of whether medically supplied nutrition and hydration constituted medical treatment. It simply stated that "[t]here is no doubt that artificial hydration and [nutrition] with a nasogastric tube constitutes a health treatment."200 The Cassazione cited Cruzan and a decision of the ECHR to support its assertion that medically supplied nutrition and hydration is a medical procedure and should not be considered basic sustenance. ${ }^{201}$

199. See infra p. 348-49.

200. Englaro VIII, supra note 140, at 18.

201. The court also supported its conclusion by indicating that the international scientific community corroborated its position that medically supplied nutrition and hydration is medical treatment. However, the court did not provide any citation or reference to support its assertion. Id. 
This position is contrary to Pope John Paul II's position that "the administration of water and food, even when provided by artificial means, always represents a natural means of preserving life, not a medical act ... and as such [is] morally obligatory." 202

The firm stance taken by the Cassazione is surprising because the issue of whether medically supplied hydration and nutrition should be considered a form of medical treatment, or basic sustenance, continues to be one of the most controversial aspects of life-sustaining treatment decisionmaking. ${ }^{203}$ Indeed, the Cassazione's position is contrary to the Italian Minister of Welfare \& Health's assertion that medically supplied nutrition and hydration is an ordinary means of care and not a medical treatment. This issue was a major point of contention and political controversy in Schiavo. ${ }^{204}$ Despite the court's strong statement, the issue may be far from settled in Italy, judging from the political response to Englaro judicial decisions.

\section{THE POLITICAL RHETORIC}

Like Schiavo, Englaro's judicial decisions caused political backlash and prompted response from other branches of the government. However the political response in Englaro took a slightly different path from that in Schiavo due to differences in the legal systems and the different stages of end-of-life decisionmaking legal development. In Englaro, the Parliament directly challenged the courts' decisions by filing an appeal to the Constitutional Court asserting that the Cassazione and the Court of Appeal's decisions violated the separation of powers principle in that their decisions created law, rather than interpreting it. Because there was no Parliamentary legislation on the issue of an incompetent patient refusing life sustaining

202. Pope John Paul II, Address of John Paul II to the Participants in the International Congress on Life-Sustaining Treatments and Vegetative State: Scientific Advances and Ethical Dilemmas (Mar. 20, 2004) available at http://www.vatican.va/holy_father/john_paul_ii/speeches/2004/march/documents/h f_jp-ii_spe_20040320_congress-fiamc_en.html (emphasis omitted).

203. THE RIGHT TO DIE, supra note 10, at § 6.03[G], § 1A.01[A].

204. Shepherd, supra note 127 , at 300. 
treatment, the judiciary's interpretation was susceptible to Parliamentary attack. Under the civil law system, the judiciary's role is to interpret law while the legislature is vested with the power to create law. However, the Constitutional Court dismissed the Parliament's appeal because the court found that the Cassazione and the Court of Appeal properly arrived at their decisions through the properly means of constitutional interpretation.

By contrast, Florida's legislature reacted to the Schiavo decisions by passing a law (known as "Terri's Law") authorizing the Governor of Florida to issue an executive order requiring reinsertion of Ms. Schiavo's PEG tube, effectively overturning a properly rendered judicial order. Because end-of-life decisionmaking laws were more developed in Florida when the Schiavo cases were decided than they were in Italy when Englaro was decided, and because the U.S. operates on a common-law rather than a civil-law system, the Florida legislature could not attack the Schiavo judicial decisions directly. Rather it attempted to statutorily overturn them, a response that, similar to the Parliamentary response to Englaro, was challenged as violating the separation of powers principle. The Florida Supreme Court held that the law was unconstitutional because it infringed upon the judiciary's power by effectively reversing a properly rendered final judgment. ${ }^{205}$ Additionally, the court held that the legislature had unconstitutionally delegated its legislative power to the executive branch by granting the governor unrestricted power to issue a stay of the treatment withdrawal without defining standards to follow in deciding when and whether to issue or end the stay.

Strikingly similar to Florida's legislative action in Schiavo, ${ }^{206}$ Italian Prime Minister Silvio Berlusconi (acting under pressure from the Church, public opinion, and his Minister of Health) ${ }^{207}$

205. Bush v. Schiavo, 885 So. $2 d$ 321, 332 (Fla. 2004).

206. In Italy, the executive branch is not a separate branch of government, but rather is a part of the Italian Parliament. See Italy, in ENCYCLOPEDIA AMERICANA: INTERNATIONAL EDITION 429, 574 (1995).

207. See Popham, Italian Coma Woman's Death Ends Berlusconi's Bid to Keep Her 
decided to intervene in the Englaro case by adopting "a law decree" under the Council of Ministers' executive authority. ${ }^{208}$ The decree is composed of only one article essentially declaring that nutrition and hydration is basic sustenance and cannot be withdrawn from patients in PVS pending legislative activity on end-of-life decisionmaking.

The Council of Ministers ${ }^{209}$ adopted the decree, but the President of the Republic, Giorgio Napolitano, rejected it, 210 refusing to sign the decree into law because he believed that it was unconstitutional for three reasons. ${ }^{211}$ First, adopting such an urgent and immediate measure could be considered a means of cutting off political debate on the issue since the Parliament was still discussing the matter. ${ }^{212}$ Second, the decree, although

Alive, supra note 151; Peter Popham, Coma Woman's Fate Left in Berlusconi's Hands; Prime Minister Wants Law to Overrule Italy's Highest Court, THE INDEPENDENT (London), Feb. 9, 2009, at 22 (both noting pressure from the Catholic Church). See Owen, Death of Coma Woman a Crime, supra note 144 (stating that Berlusconi "reportedly reacted after the Vatican Secretary of State, Cardinal Tarcisio Bertone, implored him to "stop this crime against humanity" and citing Berlusconi as saying that he "represented the feelings of most Italians," despite polls suggesting that Italians were evenly divided on the issue).

208. See Michael Day, Italy Faces Constitutional Crisis Over Coma Woman, THE OBSERVER (England), Feb. 8, 2009, at 1 (quoting Berlusconi on his decision); see Art. 77 Constituzione [Cost.](It.) (law decree may be issued out of urgency and necessity).

209. The Council of Ministers is an executive-level cabinet; the Prime Minister suggests the Ministers, and the President appoints them. See Art. 92 Constituzione [Cost.](It.). The Prime Minister serves as the President of the Council of Ministers. See Maurizio CotTa \& LUCA Verzichelli, Political Institutions in Italy 128 (figure 4.2) (2007). See also id. at 133 (figure 4.3) (depicting the structure of the Council of Ministers); ENCYCLOPEDIA AMERICANA, supra note 206, at 574 (1995)).

210. See Paddy Agnew, Italian Woman in Right-to-Die Controversy Dies, THE IRISH TIMES, Feb. 10, 2009, at 13 (noting Napolitano's rejection of the decree); Maria De Cristofaro \& Sebastian Rotella, Comatose Italian Woman Dies; Political Furor Continues, L.A. TIMES, Feb. 10, 2009, at A3 (same). As in the U.S., the President of the Republic may sign the decree into law or veto it. Unlike the structure of American government, however, the President of the Republic is a member of neither the legislative branch nor the executive branch. See THOMAS GLYN WATKIN, THE ITALIAN LEGAL TRADITION 62 (1997) ("The president is not a member of the executive and in effect stands above the other organs of government as a neutral constitutional guardian.").

211. See Letter from the President of the Republic to the President of the Council of Ministers (Feb. 6, 2009), available at http://www.quirinale.it/elementi/Continua. aspx?tipo $=4 \& k e y=8112$ (sent prior to the Council's passage of the decree).

212. Id. 
written in general and abstract terms, could be considered "exceptionally urgent" and "necessary" only if applied to Eluana Englaro herself. ${ }^{213}$ Since the courts had definitively settled Englaro, the decree violated the separation of powers principle because it effectively nullified an act of the judiciary that recognized a fundamental, constitutional right of a citizen..$^{214}$ Third, since the Cassazione had found that the right to refuse life-sustaining treatment was a fundamental right guaranteed by the Constitution, a legislative decree could not be enacted to deprive the individual of that right. ${ }^{215}$

Although this act was a product of the executive branch in Italy, its substance and effect closely resembled that of "Terri's

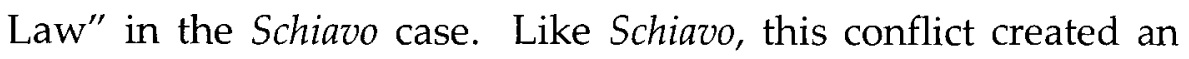
unprecedented constitutional and institutional crisis and caused a media furor. ${ }^{216}$ In the end, the constitutional crisis was avoided when Prime Minister Berlusconi and his Government changed the decree into a bill ${ }^{217}$ and presented the bill to the Senate, requesting that the Parliament approve it "ad horas." 218

213. Id.

214. Id. See also Woman Dies as Bill Passed to Keep Her Alive, THE NeW ZEALAND HERALD, Feb. 10, 2009 (citing Italian constitutional law professor as supporting the conclusion that the bill was unconstitutional for this reason).

215. See Letter from the President, supra note 211; see also NEW ZEALAND HERALD, supra note 214.

216. The political posture taken by the Prime Minister and the President mirrored Italy's division on this issue, and both sides had their supporters. See Cristofaro \& Rotella, supra note 210, at A3 (giving a sense of the deep divisions in Italy over the issue); Day, supra note 208 , at 1 (same); Day \& McVeigh, supra note 3 , at 8 (describing Englaro as having exposed "faultlines that run through Italian society, with politicians, campaigners and the church battling for the country's soul."). Prime Minister Berlusconi used the controversy to suggest that his political party and government were the only ones that tried to save an innocent life. Berlusconi also insinuated that the behavior of the President of the Republic was "pro-euthanasia" (which is a crime in Italy).

217. See Paddy Agnew, supra note 210, at 13. This move effectively changed the decree, which would have immediate legal force, into a legislative initiative requiring Parliamentary approval before having legal effect.

218. "Ad horas" means "within hours" in Latin. Prime Minister Berlusconi and his government specified a time period of three days in this instance. See Popham, Coma Woman's Fate Left in Berlusconi's Hands, supra note 207, at 22 (describing Berlusconi's "intention of ramming a regular law thorough both houses of parliament within three days"). Observers in Italy believed that a three-day time limit was significant as biblical reference, speculating that the political right-wing 
Ms. Englaro passed away while the Senate was discussing the bill. Pressure from the left-wing opposition then moved the right-wing majority, headed by Berlusconi, to abandon that bill and shifted the discussion to a more general bill on advance directives. ${ }^{219}$

As discussed previously, Englaro also had prompted the executive branch of the Lombardy Region ${ }^{220}$ to take action contrary to the judicial determinations. Ultimately, an administrative court ruled that the General Health Director could not do so. This is a contrast to the way Florida's executive branch responded to the Schiavo controversy. Because the laws establishing an individual's right to withdrawal of artificial nutrition and hydration, generally speaking, were clear in Florida, the executive branch could not openly defy the judiciary without causing a constitutional crisis. Instead, in Florida, the Department of Children and Family (DCF) sought permission from the court to intervene in the Schiavo case based on a report outlining neglect and abuse in the care of Ms. Schiavo.221 The executive branch came close to defying the judiciary when the Governor requested Florida Department of Law Enforcement agents "stand ready to seize Terri Schiavo should a 'legal widow of opportunity come.'"222 Ultimately, the executive branch did

majority meant to draw a parallel between Ms. Englaro's "promised resurrection" in three days to the number of days the Bible says that Jesus Christ spent in his tomb before resurrection. Despite medical experts' statements to the contrary, see Day, supra note 208, at 1, many believed at the time that Ms. Englaro could survive only three days without life-sustaining treatment.

219. See Federico Gustavo Pizzetti, In margine agli ultimi sviluppi del "caso Englaro": limiti della legge e "progetto di vita," POLITICA DEL DIRITTO (Mar. 5, 2009).

220. Italy is organized similarly to the United States in that its 20 regions operate with some autonomy. The Italian Constitution enumerates powers reserved to the State and those shared between the State and the regions. Those powers not enumerated are left to the regions. Art. 117 Constituzione [Cost.](It.) Five of the regions enjoy varying degrees of autonomy. Art. 116 Constituzione [Cost.](It.) See also COTTA \& VERZICHELLI, supra note 209, at 191-93.

221. William R. Levesque \& Wes Allison, Source of Claims in Schiavo Case was Abuse Hotline, ST. PETERSBURG TIMES, Mar. 4, 2005, at 1B. The judge allowed the investigation to proceed and the DCF ultimately concluded that there were no indications that Ms. Schiavo had been abused or neglected. See Chris Tisch \& Curtis Krueger, Schiavo Abuse Claims Were Old, ST. PETERSBURG TTMES, June 4, 2005, at $1 \mathrm{~A}$.

222. See Dara Kam, Agents Readied in Case 'Legal Window' Opened, PALM BEACH 
not openly defy the judiciary in America, in contrast to what happened in Italy, a testament perhaps to the different stages in end-of-life decisionmaking law of the two counties. ${ }^{223}$

\section{INSTITUTIONAL DIFFERENCES: COMMON LAW VERSUS CIVIL LAW}

Although the Cassazione's decision established that incompetent persons have the right to refuse life-prolonging treatment, it leaves future end-of-life decisionmaking cases uncertain for a variety of reasons. First, Italy is a civil law country. Under the civil law system, court decisions do not have binding authority on lower courts. ${ }^{224}$ Thus, in direct contrast to the common-law, precedent-driven system in effect in America, even a decision of the nation's highest court is not binding and serves only as persuasive authority. More important, Ms. Englaro's case was not decided by the court in plenary session, but rather by the First Civil Section of the Court. ${ }^{225}$ The fact that the case was not heard in plenary session means that the opinion would not be as persuasive when considered as part of the law in effect in later cases as if it had been decided in plenary

POST, Mar. 26, 2005, at 8.

223. The Governor's spokeswoman went on the record denying rumors that the Governor would act without judicial approval and she indicated that the Governor's office was working through the legal process. Id.

224. See Mauro Cappelletti ET Al., THE ITALian Legal SYSTEM: AN INTRODUCTION 270 (1967) ("judicial decisions are not binding precedents in subsequent cases"); however, the authors also noted that a "prior decision is, in realistic if not in formal terms, a precedent." Id. at 272. See also Vincenzo Varano, Machinery of Justice, in INTRODUCTION TO ITALIAN LAW 99, 111 (Jeffrey S. Lena \& Ugo Mattei eds., 2002) ("decisions, even if issued by the plenary session of the Supreme Court [of Cassazaione], do not bind lower courts, as would be the case in a common law jurisdiction, although they do enjoy a strong persuasive authority"). For a discussion on the wider role of precedents in the civil law system, see Mauro Cappelletti, The Doctrine of Stare Decisis and the Civil Law: A Fundamental Differenceor no Difference at All?, in Festschrift für Konrad Zweigert: ZUM 70. GEBURTSTAG 381 (Herbert Bernstein et al. eds. 1981).

225. The Supreme Court of Cassation is divided into three civil and six criminal divisions, with five members per section. In cases of importance or cases that involve conflict of decisions decided by different sections of the court, the decision is given by a "plenary session (sezioni unite)" composed of a panel of nine judges selected from all sections of the Court. Until an issue has been decided by a plenary session, there is the possibility of conflicting Court of Cassation precedents. Vincenzo Varano, supra note 224, at 108. 
session. Consequently, future cases with similar facts could be decided differently than Ms. Englaro's case.226

That the Constitutional Court did not find a separation of powers violation in the Cassazione's decision might indicate that the Constitutional Court tacitly agreed with the substance of the decision. However, that inference could be proven false because the Constitutional Court has not stated that the Cassazione's interpretation is the only interpretation possible.

\section{LEgISLATIVE DEVELOPMENT OF ADVANCE DIRECTIVES}

Similar to Quinlan, which prompted legislative activities in various American states, the Cassazione's decision has also given weight to debate regarding advance directives in Italy.227 Efforts in the Italian Parliament to pass a statute specifically authorizing advance directives began long before ${ }^{228}$ the Cassazione's decision in Englaro, ${ }^{229}$ and they continued during

226. After Englaro, a section of the Cassazione specializing in tort law confirmed that a person anticipatorily may refuse any life-sustaining treatment, but required specific, informed, written instructions to that effect. See the Court of Cassazione, sect. III, sent. 15 Sept. 2008, n. 23676 (specializing in tort law).

227. See also Donald Carroll \& Christine Marciasini, Advance Care Directives: Florida, Italy and the Holy Grail of Wishes, E-REPORT (ABA SECTION OF REAL PROPERTY, TRUST \& ESTATE LAW) Oct. 2008, at 4, available at http://www.abanet.org /rpte/publications/ereport/2008/5/TE_CarrollMarciasini_Advance.pdf (noting that legislation authorizing advance directives would assist in cases such as Englaro because it would "allow an individual to express his or her health care wishes clearly"). After Ms. Englaro died, "some Italians began using YouTube to post their own living wills" in an attempt to circumvent their country's lack of advance directive legislation. See Donadio, supra note 144 , at A7.

228. See generally FEDERICO GuSTAVO PIZZETTI, ALLE FRONTIERE DELLA VITA: IL TESTAMENTO BIOLOGICO TRA VALORI COSTITUZionali E PROMOzIONE DELla PERSONA (Giuffré 2008).

229. In 2003, Italy's National Committee for Bioethics (the Committee) produced a document providing the Legislature with a unanimous, balanced view of advance directives to use in lawmaking. In 2006, the Committee produced a second document, this one approved by only a majority over strong opposition, about the refusal of medically supplied nutrition and hydration. See generally Presidenza del Consiglio dei Ministri, Comitato Nazionale Per La Bioetica, L'Alimentazione e L'Idratazione di Pazienti in Stato Vegetativo Persistente, GoVERNO ITALIANO (Sept. 30, 2005), http://www.governo.it/bioetica/testi/PEG.pdf. The Tribunal of Lecco cited the 2006 document as supporting the view that the administration of medically supplied nutrition and hydration is ordinary care, not capable of being refused unless it cannot be metabolized and death is imminent. See also Presidenza del Consiglio dei Ministri, Comitato Nazionale Per La Bioetica, 
those case proceedings. Shortly after the Cassazione's judgment, unforeseen elections in early spring 2008 interrupted the legislative process. Efforts restarted with a differentlyconstituted Parliament, with a different political majority, but slowed once again when both Houses of the Italian Parliament became involved in the Englaro litigation. ${ }^{230}$ The process, however, picked up a great deal of speed in the Italian Senate after Ms. Englaro's death, with strong conflicts emerging between opposing political parties. ${ }^{231}$ The overall framework of the proposed legislation in the Italian Parliament divides neatly into distinct sub-sections for purposes of analysis. It specifically governs both informed consent and what Americans would call advance directives, to be called "anticipated declarations of treatment" (ADT) in Italy. ${ }^{232}$ The major substantive portions of

Rifiuto e Rinuncia Conssapevole al Trattamento Sanitario nella Relazione Paziente-Medico, GOVERNO ITALIANO http://www.governo.it/bioetica/testi/Rifiuto_postille_9_11

2088.pdf. For a discussion of the 2006 Committee document, see Gilda Ferrando, Nutrizione e Idratazione dei Pazienti in SVP: a Proposito del Parere del CNB del 30 settembre 2005, 13 BIOETICA 85 (2005). More recently, in June 2009, the Italian Medical Association adopted a document, available at http://portale.fnomceo.it /PortaleFnomceo/showItem.2puntOT?id=66102, stating that the provision of medically supplied nutrition and hydration is a medical practice that the patient may refuse as an exercise of his or her liberty right.

230. See infra p. 320-28 (describing the recourse for conflict of attribution).

231. The text that first the Hygiene and Health Senate Commission, and subsequently the entire Senate debated during the early spring of 2009 (quite quickly because of the strong will of the political majority to adopt the new legislation as soon as possible), was an amalgam of the different proposals previously presented by various senators, elaborated and drafted by senator Calabro (n. A.S. 10). The Senate approved that text, with some amendments, on March 26, 2009 (with 150 yays, 123 nays and 3 absentees). Shortly thereafter, the bill went to the other Parliamentary body, the House of Deputies, where it is pending (n. A.C. 2350). In the Italian constitutional system, the President of the Republic may sign a bill into law only if both the Senate and the House of Deputies have approved the same text. See Arts. 70-73 Constituzione [Cost.] (It.).

232. Members of the Italian Parliament wished to avoid using the term "directive" because they did not wish to accord these documents with rigidly binding force, and similarly wished to avoid use of the term "living will" to avoid the strictly binding nature of testamentary written wills. While patients' wishes with regard to end-of-life care should be binding, it is true that strict application is not always possible because patients cannot predict their exact medical conditions or precisely what medical treatment they might need near the ends of their lives. See THE RIGHT TO DIE, supra note 10, at \$7.02[B] (discussing advance decisionmaking). Cf. Kathy L. Cerminara, An Analysis of H.701, UnIV. OF Miami ETHICS PROGRAM, 4 (Feb. 25, 2005), http://www6.miami.edu/ethics/schiavo/ 
the proposed legislation are Article 2, governing informed consent, and Articles 3, 4, and 6 through 8, which introduce ADTs into the legal system.

\section{The Foundational Provisions of Italy's Proposed Legislation}

Like many legislatures in America, ${ }^{233}$ the Italian Parliament began by setting forth some overarching principles in the context of which those working with the law could construe its primary provisions. For example, the Italian Parliament noted that the recognition and protection of human life, which it expressly states is an "inviolable and inalienable right," must be guaranteed to terminally ill patients, even those who are incompetent, until they die. It also emphasized, however, recognizing the dignity of each person, over and above the interests of society, technology, or science. It reiterated the Italian criminal code's prohibition of euthanasia and assisted suicide, noting that medicine must be devoted to the protection of life and health and the relief of suffering. ${ }^{234}$ The Parliament also recognized the "priority" of the therapeutic relationship existing between physicians and patients, particularly important near the end of life, and it highlighted the importance of the informed consent principle. Finally, and importantly, it stated that when a patient is at the end of life, or in a "condition of death foreseen as imminent," physicians have a duty to abstain from treatments that are "extraordinary," "not proportionate," "not efficient," or inadequate to treat the terminal condition.

In Article 2 of the proposed legislation, the Parliament traced the provisions of Article 5 of the Oviedo Convention

pdf_files/030805- HB701-LegalAnalysis.pdf.

233. See, e.g., FLA. STAT. ANN. § 765.102 (2010) (legislative findings and intent).

234. The provisions of the criminal code to which this section referred generally relate to homicide of a person consenting to be killed and instigation or assistance of suicide; they do not relate specifically to any of these crimes occurring in a medical context. Therefore, one could argue that the legislature has written new prohibitions into this legislation by interpreting previously existing general criminal codes to apply to a specific situation. Doing so arguably would contravene the Italian Constitution's requirement that criminal provisions be specific. 
addressing informed consent. ${ }^{235}$ Unless a patient is incompetent and his or her life is in peril, the physician must accurately inform ${ }^{236}$ that patient of diagnosis, prognosis, the nature of the treatment proposed, treatment objectives, probable risks and benefits, foreseeable side effects, practicable alternatives, and the consequences of refusal of treatment. The law requires that a written document memorializing the consent be entered into the patient's medical record. Patients retain the right to revoke consent, in full or in part, at any time.

If a patient is incompetent and his or her life is not in peril, physicians must obtain consent from someone speaking on behalf of the patient. This could be a health care proxy (someone appointed through an ADT) or a court-appointed guardian. If the patient is a minor, his or her parents are responsible for consenting, and they are to pay attention to their child's wishes when doing so. In general, in fact, the responsibility of those consenting on behalf of incompetent patients is to keep both the patients' physical and psychological health in mind.

\section{Italy's Proposed ADTs}

Most importantly, the proposed legislation authorizes ADTs, through which those who are fully capable and informed ${ }^{237}$ may express their wishes regarding future treatment. The ADT must be written, dated and signed by both the patient and the patient's attending physician. ${ }^{238}$ It will

235. As noted previously, see supra note 186, Parliament had previously ratified the Convention of Oviedo, an international treaty, but the convention has no legal force in Italy standing independently because that country's president had never ratified it. See Pizzetti, supra note 186 . This proposed legislation essentially would give legal force to that portion of the treaty.

236. The patient may refuse the information.

237. One wonders the extent to which patients acting anticipatorily can be informed. To some extent, it is difficult to predict what will occur near the end of a patient's life. This is why requiring a high degree of information before making an advance directive, or requiring a high degree of specificity in an advance directive will reduce the effectiveness of such directives. See Cerminara, Tracking the Storm, supra note 91, at 173 n.124; see also Cerminara, An Analysis of H.701, supra note 232.

238. Proposta di Legge 26 marzo 2009, n. 2350 (It). Art. 4, sect. 1, 2. 
remain valid for five years unless revoked or modified before the expiration of that time period. It also may be renewed as many times as the declarant likes. ${ }^{239}$

One form of ADT resembles a living will. Using an ADT, a declarant may request treatment, or may refuse treatment that is "not proportionate" 240 and would not be required by the law or medical ethics. ${ }^{241}$ The declarant may not request assistance in dying or euthanasia. ${ }^{242}$ Importantly, the declarant also may not refuse medically supplied nutrition and hydration, for the Parliament has deemed those to be forms of vital sustenance physiologically tied to pain relief at the end of life. ${ }^{243}$ ADTs become effective when a medical pane ${ }^{244}$ has determined that the patient cannot make a medical decision because of incompetency through a vegetative state. ${ }^{245}$

Another form of ADT resembles the various sorts of instruments pursuant to which patients in the United States appoint surrogate decisionmakers. Using an ADT, a declarant may appoint a "fiduciary," who must be a competent adult who also signs the appointment. ${ }^{246}$ This person, who becomes the only one authorized to discuss the patient's condition with his or her doctors, is statutorily required to act in the "exclusive and best interest" of the patient, following only the wishes the

239. Art. 4 , sect. 3,4 .

240. Art. 3 , sect. 3 .

241. Art 3 , sect. 2.

242. Art. 3 , sect. 4.

243. Art. 3, sect. 5.

244. The medical panel would be comprised of a coroner, an anesthetist and a neurologist, with participation from the attending physician and a specialist in the area medicine relevant to the patient's condition.

245. Art. 3, sect. 6. The Parliament did not require that a patient be in a persistent or permanent vegetative state, perhaps because of advice to that effect from an ad hoc work group appointed by the Minister of Labour, Health \& Social Policies (Welfare) (at the time only Minister of Health). See http://www.ministerosalute.it /imgs/C_17_primopianoNuovo_201_documenti_itemDocumenti_0_fileDocumento. pdf (Nov. 17, 2008) (strongly recommending abandonment of those terms). Another work group, appointed five years previously by a different Minister of Health, had advised to the contrary. See Zadig (reprinting from Bioetica n. 2/2001) (on file with author).

246. Art. 6. 
incompetent expressed in the ADT. The fiduciary must guard against homicide or assisted suicide occurring.

One major struggle in the Senate concerned whether ADTs would be mandatory, in two vastly different ways. The Senate considered the following options:

(a) Patients would be required to complete ADTs, which would then be binding on their attending physicians;

(b) Patients would not be required to complete ADTs, but if completed they would be binding on their attending physicians; or

(c) Patients would not be required to complete ADTs, and physicians could consider them to be advisory, but not binding, on their actions.

The result in Italy's proposed legislation was the third option. Article 7 of the proposed legislation makes clear that citizens need not execute ADTs if they choose not to do so. Moreover, it specifies that they do not bind attending physicians; instead they are to be "taken into account" by the physicians. In fact, a physician considering whether to follow an ADT must memorialize in the patient's medical record the reason why he or she either chose or chose not to follow the ADT. ${ }^{247}$ In making this decision, the physician must evaluate the patient's ADT and the views of any fiduciary the patient named, his or her scientific views, his or her conscience, the principle of the "inviolability of human life," the importance of the "preservation of health," and the principles of "precaution, " "proportionality," and "prudence." 248 In any event, whatever a physician chooses to do, he or she cannot comply with instructions to affirmatively cause the patient's death or instructions that would otherwise be contrary to the law or medical ethics. ${ }^{249}$

247. Art. 7, sect. 1 .

248. Art. 7, sect. 2.

249. Id 


\section{Englaro and Italy's Proposed Legislation}

While a step toward respecting patient autonomy in the sense that it would permit incompetent patients to memorialize their wishes with respect to health care decisions, Italy's proposed legislation directly contradicts many of the major principles underlying the Englaro decisions. Certainly the Cassazione ruled, contrary to this proposed legislation, that medically supplied nutrition and hydration is a medical treatment capable of refusal on the same basis as any other treatment, whereas the proposed legislation would prohibit withholding or withdrawal of it. Even more broadly, and more striking, however, is the proposed legislation's narrowing of the robust constitutional principles of bodily integrity and autonomy apparent in the court's decision.

The Cassazione found broad, inviolate, fundamental rights of human dignity and personal identity that reach much further than the proposed legislation would. Absent from this proposed legislation is any recognition that human dignity and personal identity is a deeply personal matter, to be determined by each individual for him or herself, no matter what the interests of society and science are. The fiduciary is to act in the patient's best interests, following only the wishes the patient had expressed in his or her ADT, whereas the court in Englaro recognized that a variety of information about the patient would be relevant to the determination of what he or she would have wanted in terms of treatment, which it held to be the important goal of end-of-life decisionmaking. Similarly, the patient is not permitted to bind anyone later with his or her wishes. Regardless of what a patient or that patient's fiduciary says, the physician may decide not to follow the ADT with no consequence, as long as he or she memorializes the reason for doing so.

The end result is a complex body of norms governing physicians' interpretations and applications of (or decisions not to apply) ADTs, with additional reminders that euthanasia is 
prohibited and the right to life in inalienable. That euthanasia is prohibited is generally accepted, not only in Italy but also in most countries. ${ }^{250}$ That the right to life is unalienable is incontestable, at least if this adjective is interpreted in the sense that life cannot be sold. What is left as groundbreaking in this proposed legislation is a set of rules that gives incompetent patients the ability to express their wishes but robs that expression of actual effect.

Of course, end-of-life decisionmaking is always a balancing act between the interest in preserving life and health and patient autonomy. If a patient has a reasonable hope of recovery, what the Italian Parliament has declared to be a right to life likely should prevail, especially when the incompetent patient has left no indication that he or she might wish otherwise. Yet autonomy, as an expression of human dignity and personal identity, is sufficiently important that advance directives should always bind decisionmakers for incompetent patients to act in accordance with the patient's values, goals, and desires. In any particular case, the precise details of exactly which treatments should be withheld or withdrawn, and the precise time at which to do so, must be left to a presently, currently competent, decisionmaker, who must make such decisions in accordance with the patient's overall values, goals and desires.

In the proposed legislation, the Parliament seems to have been so focused on protecting the right to life and the principle of preservation of health that it greatly diminished the principle of patient self-determination. The overall structure of this proposed legislation, including the general principles the Parliament was so careful to delineate, is intended to apply in every case, despite each patient's unique situation. For example, two important goals of medicine are to preserve health and alleviate suffering, as the proposed legislation states. However, relying solely on the fact that those are important goals casts aside the importance of the patient's subjective evaluation of his

250. The Netherlands and Switzerland are two notable exceptions. See THE RIGHT TO DIE, supra note 10 , at $\S 12$. 
or her own "health" and "suffering." The Court of Cassation recognized that prolonging a patient's life in a terminal condition or a persistent vegetative state could be unbearable at different stages for various patients. It was willing to give those patients the right to refuse treatment, whereas the Parliament would give physicians the right to override any desire a patient had to refuse treatment depending on the physicians' beliefs that treatment was required to serve the goals of medicine the Parliament had listed.

Moreover, the statute is curiously limiting in its terms. It expressly contemplates only consent for treatment or refusal of treatment in section 2; in the sections on ADTs, those instruments similarly are designed to provide guidance on "activation" or "non-activation" of treatment. Nowhere is provision expressly made for authorization of the withdrawal of treatment to which the patient previously had consented. The result, if narrowly interpreted, without consideration of section 2, could be that a treatment once started can never be withdrawn, which could in turn discourage trying continuing treatments that might not work, for fear that they can never later be withdrawn.

Even more important, while advance directives in America are primarily used to express views regarding life-sustaining treatment, the withholding or withdrawal of which would result in the patient's death, various portions of the proposed legislation in Italy seem to prohibit ADTs from being used for that purpose in that country. Article 2, section 9 emphasizes that physicians may proceed without informed consent when an incompetent patient is in an emergency condition. Potentially building upon that, the wording of Article 4, section 6 specifies that an ADT does not apply when the patient is in an emergency condition or when the patient's life is in imminent danger. ${ }^{251}$

251. The combined interpretation of Article 2, Section 9 and Article 4, section 6 could result in great ambiguity in certain circumstances. Article 4, section 6 is rather unremarkable if it simply reinforces Article 2, Section 9 by specifying that treatment should be administered if there is an emergency situation and the physician or the fiduciary is unable to find the patient's ADT. It similarly is 
Article 1, section 1(c) refers to medicine as being exclusively devoted to the defense of life. And Article 7, section 2 advises physicians that they are to follow the principle of inviolability of life when interpreting a patient's ADT. The Cassazione expressly held in Englaro that both competent and incompetent patients possessed a right to refuse medical treatment, rooted in the constitutional principles of human dignity and identity, encompassing decisions to withhold even life-sustaining treatment. The Parliament has not clearly stated this, which could result in controversy when an incompetent patient has expressed a wish to do so in his or her ADT and the attending physician is attempting to decide whether to follow the patient's wish.

On another, different, point, the Parliament has chosen a curiously limiting triggering condition as the point at which patients' ADTs would become effective. The proposed legislation provides that the ADT will become "relevant" only when the unconscious patient is in a vegetative state. Strictly interpreting the proposed legislation would prohibit consideration of a patient's wishes as expressed in an ADT when the patient is incompetent for some other reason. For example, if a patient is in the late stages of Alzheimer's disease but is not in a vegetative state, his or her ADT would have no effect under a strict interpretation of the proposed legislation. In reality, considering this limited triggering condition and the fact that patients may not refuse medically supplied nutrition and hydration, the proposed legislation has a very narrow range of application indeed.

somewhat (although less) straightforward in application if it means that treatment should be administered if there is an emergency situation and the physician or fiduciary must act before there is time to read and understand an ADT. The combination of Article 2, Section 9 and Article 4, section 6, however, has the potential to eviscerate the rest of the legislation if it is read to imply that treatment is to be administered in any emergency condition, even when an ADT is fully known and applicable, or, worse yet, even if the emergency condition arose because of application of the ADT (as, for example, when a ventilator is removed and the patient begins to die from lack of oxygen). The latter interpretation would be inconsistent with the very existence of the statute. 
It would be a mistake, in any event, to believe that the failure of this proposed bill to pass Parliament means that individuals are powerless to execute legal instruments to plan for medical treatment decisions when they are unable to give informed consent. Even leaving aside the constitutional provisions at issue in Englaro, Italian law currently presents a framework within which patients who wish to memorialize instructions for future care may do so. In 2006, Italian law was amended to provide for the appointment of an "amministratore di sostegno" for an incompetent patient. Similar to a guardian, this person could conceivably act as a health care proxy if a patient so chose, upon that patient's incompetency.

Three peculiarities of the law governing such amministratores seem to make the authorization of such persons to act on behalf of patients equivalent to patients' abilities to execute advance directives. First, the process by which an amministratore is chosen can resemble a health care proxy designation; even if the court overseeing the patient's guardianship proceeding appoints the amministratore, the patient/ward is entitled to have designated his or her amministratore in advance..$^{252}$ Second, when the guardianship court establishes the amministratore's powers, it considers the specific needs and conditions of the patient/ward, incorporating a great deal of flexibility in accordance with particular conditions and the patient/ward's previously manifested wishes. ${ }^{253}$ Finally, the patient/ward may leave the amministratore a set of directives authenticated by a notary, thus in effect leaving a living will for the amministratore to follow.

Using the appointment of an amministratore to serve the same goals as an advance directive would serve could be

252. See Federico G. Pizzetti, Il Disegno di Legge Governativo sui "DICO" e il Testamento Biologico: Spunti di Riflessione, in INIZIO E FINE VITA: SOGGETTI, DiRITTI, CONFLITTI 56 (Federico G. Pizzetti \& Marzia Rosti eds., Giuffrè 2007).

253. See generally EMANUELE CALÒ, AMMinistraZIONE DI SOSTEGNO: LEGGE 9 GENNAIO 2004, N. 6 (Giuffrè 2004). 
controversial. Amministratores are supposed to be appointed when a patient/ward is not fully deprived of competence but instead when he or she suffers some physical or mental illness that impairs the ability to live in full autonomy. ${ }^{254}$ Extension of the concept into the situation in which a patient is permanently unconscious, as Ms. Englaro was, might be questioned. Similarly, it is unclear whether amministratores' powers may include health care decisionmaking powers, especially end-oflife health care decisionmaking powers. ${ }^{255}$

Recent cases, however, have indicated that this is possible. Many cases before the Guardianship Court in Modena ${ }^{256}$ have opened the door to the use of this tool with respect to health care decisions, even in order to withhold or withdraw life-sustaining and life-saving devices. Doing so would compensate for the lack of specific legislation about advance directives in Italy and in fact might prove to be more expansive than the proposed legislation pending before Parliament at this time. If this trend in the law continues, and the proposed legislation does not take effect, future patients may attempt to vest their amministratores $d i$ sostegno with the powers of a health care proxy in an attempt to provide instructions for end-of-life care in a period of future incapacity.

254. According to Corte Cost., sent. 9 December 2005, n. 440, acting pursuant to the amministrazione di sostegno proceeding differs from a guardianship. The first legal device is not a substitute for the second. Thus, it is possible that a judge does not have the power to appoint an amministratore instead of a guardian or a proxy when the patient is completely lacking capacity - as in the vegetative state, for example.

255. See Michele Sesta, Quali Strumenti per Attuare le Direttive Anticipate?, in TESTAMENTO BIOLOGICO. RIFLESSIONI DI DIECI GIURISTI 163 (Umberto Veronesi Foundation 2006), available at http://www.fondazioneveronesi.it/allegati/Integrale

TestBIO.pdf; see also Giovanni Bonilini, Testamento di Vita ed Amministrazione di Sostegno, in TESTAMENTO BIOLOGICO. RIFLESSIONI DI DIECI GIURISTI 189 (Umberto Veronesi Foundation 2006).

256. Cfr. Tribunal of Modena, decree., 5 Nov. 2008 e Tribunal of Modena, decree, 13 May 2008, e, in parte, anche Tribunal of Siena, decree, 18 June 2007 e Tribunal of Roma, decree, 20 Dec. 2005. 


\section{CONCLUSION}

The Cassazione's decision is Italy's first substantial step toward establishing a body of end-of-life decisionmaking case law. In many ways, the Cassazione's decision mirrors Quinlan; it is the first major decision in Italy to declare that an incompetent patient can have life-sustaining treatment withdrawn or withheld. Quinlan prompted U.S. state legislatures to enact advance directive statues, ${ }^{257}$ and indeed, there is Parliamentary activity in Italy to that effect.

The Cassazione's decision is significant in its breadth. By locating the right to refuse life-sustaining treatment within the combined meaning of specific constitutional provisions guaranteeing human dignity, integrity, and liberty, the Italian court has established a firmer basis for refusal of treatment in that country than U.S. Supreme Court decisions currently support in America. In the United States, the Supreme Court has been parsimonious, holding that, even with a constitutional basis, the right to refuse life-sustaining treatment has its roots in tort-law principles preventing unwanted touching. The Italian conception of the right potentially encompasses a more expansive list of intimate medical decisions, although the Cassazione took pains to draw the line before permitting assistance to terminally ill people in ending their lives.

There remain, however, many issues in end-of-life decisionmaking law that have not yet been resolved in Italy. Although the court in Englaro appeared to announce a clear and convincing evidentiary standard, the boundary of that standard has yet to be tested. Englaro's facts exceeded that standard because all evidence pointed to the conclusion that Ms. Englaro

257. The intermediate appellate court decision in Quinlan appeared in 1975. See In re Quinlan, 348 A.2d 801 (N.J. Super. Ct., Ch. Div. 1975), rev'd, 355 A.2d 647 (N.J. 1976). California passed the first advance directive statute in the United States the following year, 1976. See THE RIGHT TO DIE, supra note 10, at $\S 7.01[A]$ at 7-7. See also Norman Cantor, Twenty-Five Years After Quinlan: A Review of the Jurisprudence of Death and Dying, 29 J. L. MED. \& ETHICS 182, 182 (2001) ("Starting in 1976, with the Quinlan case in New Jersey, courts and legislatures have outlined the legal bounds governing medical conduct vis-à-vis the dying process.") (emphasis added). 
would have wished to discontinue life-sustaining treatment. The Italian courts have yet to face a situation like Schiavo, in which private parties bring a dispute to court.

More important, the Italian Parliament appears to be likely to differ from the court in major ways. It disagrees with the court on the politically controversial issue of whether medically supplied hydration and nutrition is medical treatment that a patient may refuse. It would pass a statute that reflects a much more cramped version of patient autonomy than the court's vision of that constitutional right. In a number of ways, while Italy, in Englaro, has somewhat mimicked the United States in judicial development of end-of-life decisionmaking law, institutional differences seem to be leading it down a different path in the Parliament.

Interestingly, it seems as if Italy's path toward patients preserving robust end-of-life decisionmaking power even in incompetency lies not through the Parliament in the future but through past actions of the Parliament. If the current proposed legislation fails, it is possible that patients and the courts can build upon the groundwork already established through the Italian constitution and the statutory tool of the amministratore $d i$ sostegno to secure robust patient autonomy near the end of life. The road may not end so far from that of the United States after all, but only after taking some twists and turns. 